Historic, archived document

Do not assume content reflects current scientific knowledge, policies, or practices. 

FE
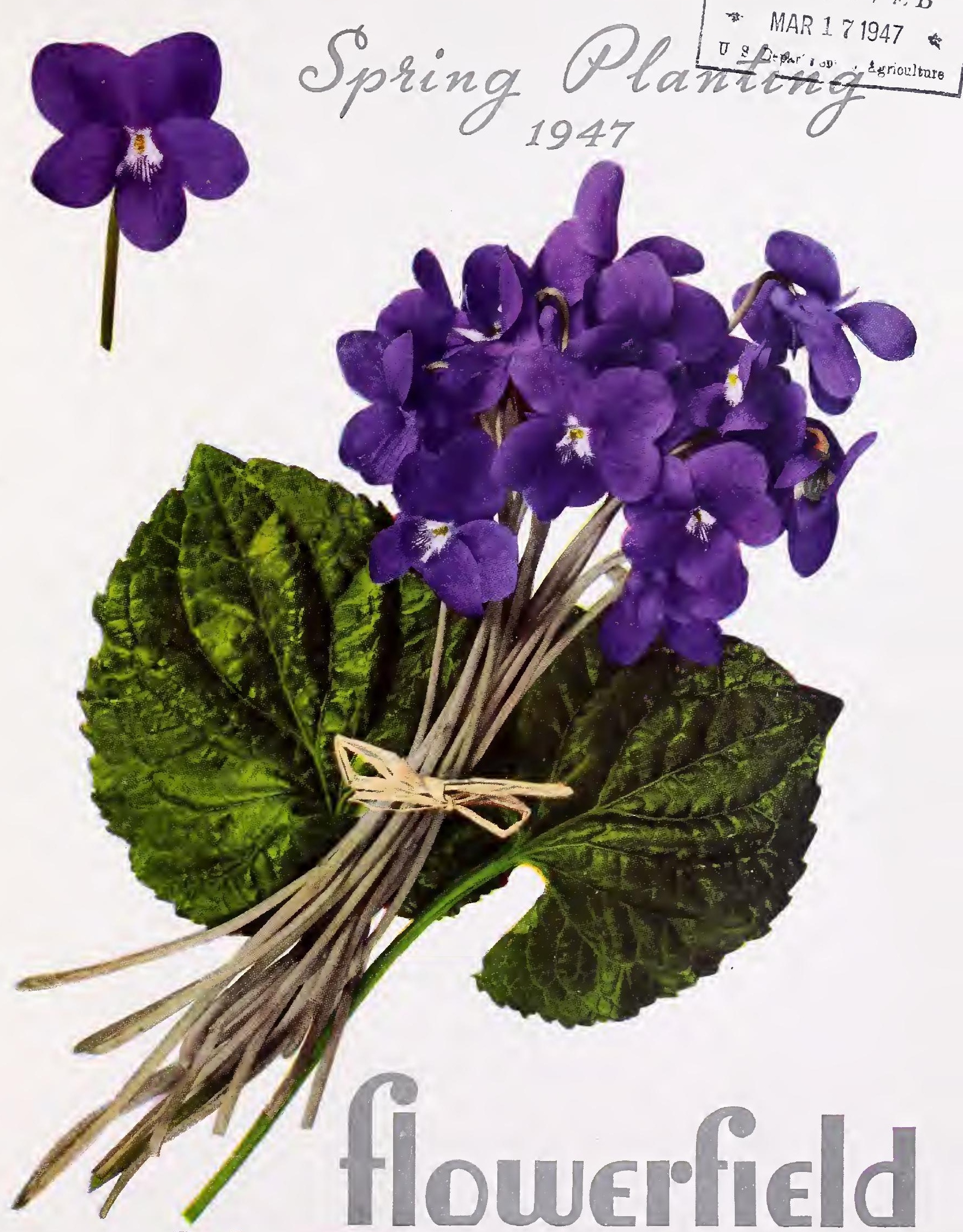

VIOLET Rroyul Rolie

3 for $\$ 1.75$

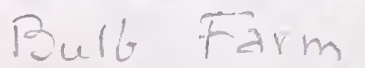




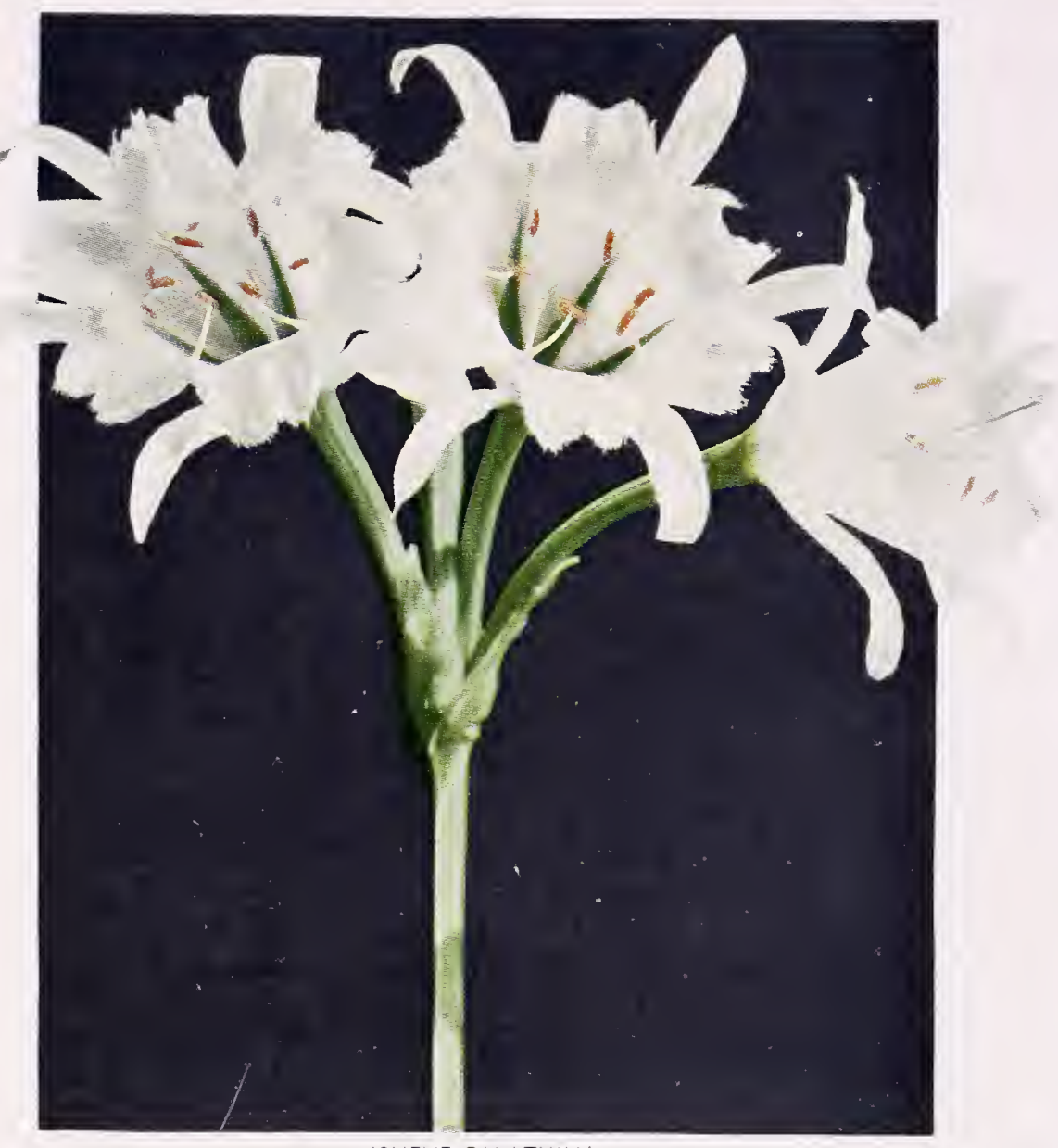

\section{Flowerfield's ISMENE CALATHINA}

Ismene Calathina is one of the choicest of all garden bulbs. It is known by many namcs, Peruvian Daffodil, the Spider Lily and Basket Flower. By any of its names it is equally lovely. The flowers are large, umbellate, and snowy white, measuring four to five inches across. Glossy green markings deep in the throat of the flower make a charming contrast. There is a delightful fragrance from these flowers which on still warm evenings scents the whole garden. Plant in well-drained soil in June when the ground is well warmed for flowers in late July or August.

Flowerfield's large bulbs produce two to five blooms on stems two to two and one-half feet tall.

Monster bulbs, Each 85c, Doz. \$8.50

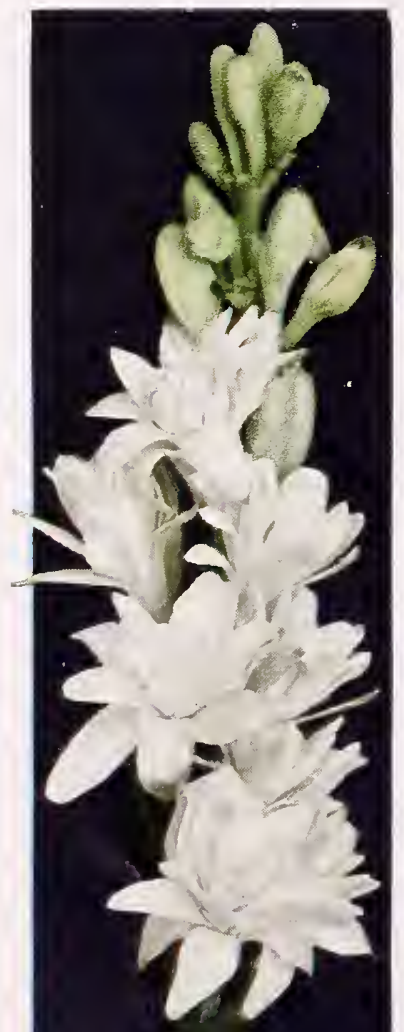

\section{HELLEBORUS}

Helleborus Niger, the Christmas Rose, is the plant that blooms in the winter. A low growing plant, 12 to 16 inches high, with broad, leathery, palmlike leaves that remain evergreen. The large single white blossoms appear from December to February. Neither cold nor snow deters the plant from blooming. Extremely hardy. It may be planted in spring or fall. Water well in the hot summer and top dress with leaf mold or well-rotted manure in the fall. Left in a permanent location it will thrive for years.

Each $\$ 1.25$, Three $\$ 3.50$, Doz. $\$ 12.50$

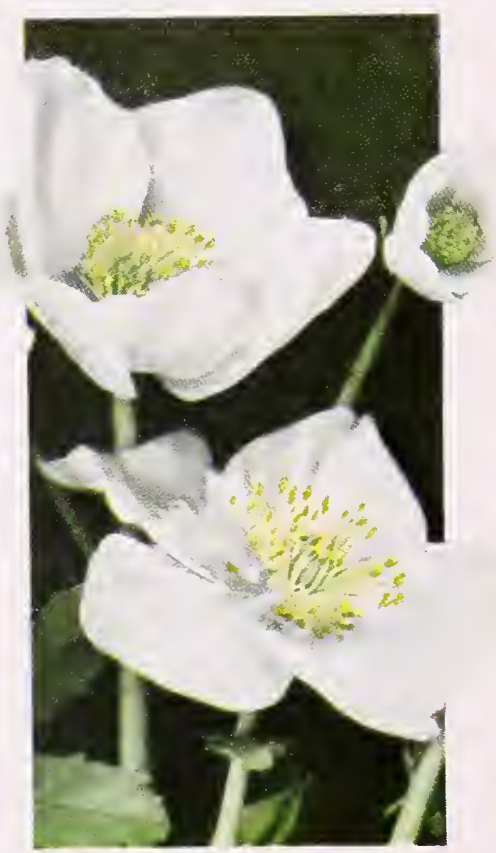

HELLEBORUS

\section{TUBEROSE}

Tuberoses are among the choicest of flowers. They produce long spikes (two to three feet high) of pure white, waxlike flowers of great fragrance and beauty. Bulbs may be planted from April to June, in pots or in the open ground and should be set three inches deep in good rich soil. Do not allow them to be overrun with weeds or other plants if you desire them to bloom early. 


\section{Flowerfield's \\ BULB AND PLANT CATALOG \\ SPRING 1947}

Flowerfield Bulb Farm was established on Long Island in the seed and bulb business in 1874, where it became one of the most reputable distributors and growers of its time. We are justly proud of the part Flowerfield has contributed to American Horticulture, and in the traditions in which it continues to serve.
As growers, we are proud of our stock and are willing to back up that pride by guaranteeing all our products to the limit. Flowerfield grows and sells healthy products only. From our 360 -acre farm on Long Island our bulbs, seeds and plants are known the world over for their superior root system, size and vigor.

\section{N DEX}

\begin{tabular}{|c|c|}
\hline Amarcrinum & Columbine ... \\
\hline Amaryllis ... & Cushion Mums \\
\hline Aquilegia . & Dahlias ....... \\
\hline Asters ... & Dahlias, Giant. . 14-15 \\
\hline Astilbe & Dahlias, Miniature 17 \\
\hline Baby's Breath & Dahlias, Pompon . 16 \\
\hline Begonias, Tuberous $4-5$ & Dahlias, Single . \\
\hline Bleeding Heart 32 & Daisy, Shasta . \\
\hline Caladium & Daylilies .... \\
\hline Callas . . & Delphinium . \\
\hline Cannas ...... & Dianthus ..... \\
\hline Carnations .... & Dicentra Eximia . . 32 \\
\hline Christmas Rose ... 2 & $\begin{array}{l}\text { Fragrant Peren- } \\
\text { nials } \ldots \ldots \ldots 24-25\end{array}$ \\
\hline $\begin{array}{l}\text { Chrysan themums } 37.42 \\
\text { Chrysanthemum. }\end{array}$ & Funkia $\ldots \ldots \ldots \ldots r$ \\
\hline Cushion ..... $41-42$ & Gaillardia ... \\
\hline $\begin{array}{l}\text { Chrysanthemum, } \\
\text { Spoon }\end{array}$ & $\begin{array}{l}\text { Gladiolus } \\
\text { Gloriosa Lily }\end{array}$ \\
\hline
\end{tabular}

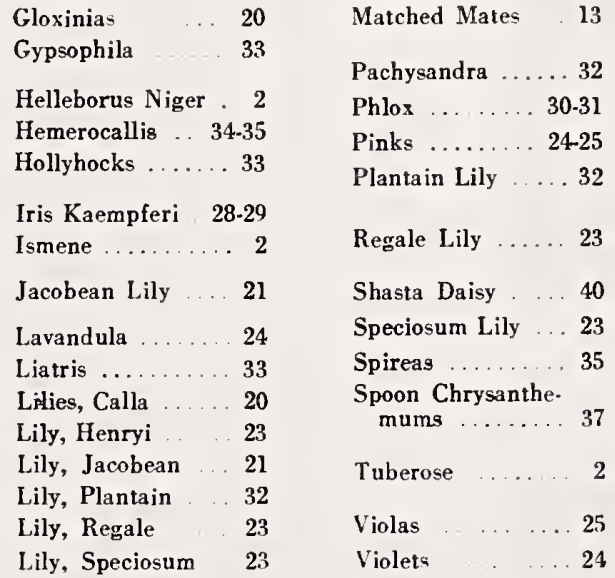

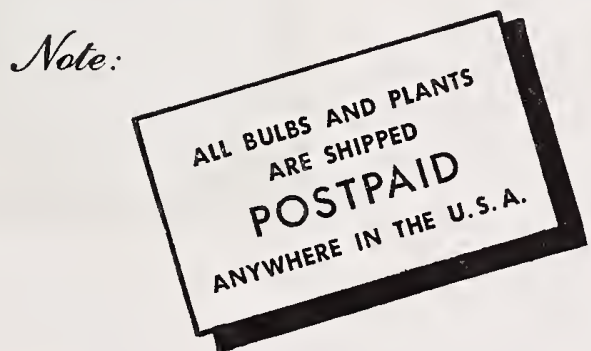

Our plants and bulbs, guaranteed to reach you in good condition, are carefully packed in scientifically prepared corrugated boxes. Special preparations are made to protect deliveries to all parts of the world. Plants are freshly dug and packed in sphagnum moss and water-proof paper. Bulbs are kept in ideal storage conditions, are hand sorted and selected true to name for your individual orders.

In order to serve you better, Flowerfield suggests that you order your selections as soon as possible. This will allow our staff to prepare acknowledgements of your orders and allocate stock for shipment to you at the ideal time for planting.

Complete cultural directions will be included with acknowledgement of your order.

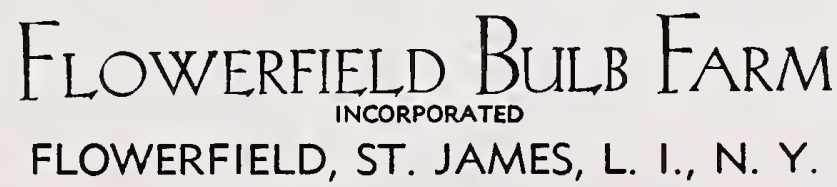




\section{Giant Frtwoud TUBEROUS-ROOTED BEGONIAS}

These colorful, exquisite flowers are unlike most bulbs for tuberous rooted Begonias actually need shade and should be shielded from the sun's rays. When planted in a moist, fairly rich soil, they require little care.

Beginning in July, tuberous rooted Begonias carry their many huge flowers in a wide range of pastel and bright colors, from pure white to yellow, pink and deep rich crimson. The flowers bloom in clusters of three, one large male flower in the center and two smaller female flowers on either side. These side buds should be removed as soon as they appear; they are single-type flowers of inferior character and inhibit the full development of the central flower. Under ordinary culture these blooms will reach 5 to 6 inches in diameter, although flowers up to 8 inches may be obtained by special care and attention.

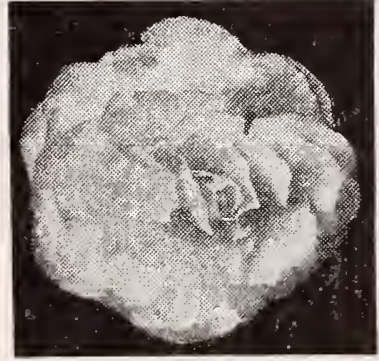

\section{CAMELLIA- FLOWERED}

The King of Begonias appear to be huge Camellias. These com. pletely double blooms are far larger than the best greenhouse Camellias. The illustration on the facing page more adequately describes the beauty of this unusual variety.

Red, Three $\$ 1.00 \bullet \quad$ Pink, Three $\$ 1.00 \bullet \quad$ White, Three $\$ 1.15$ Rose, Three \$1.00 - Yellow, Three \$1.15 Mixed Camellia-Flowered, Three $\$ 1.00$, Doz. $\$ 3.50$

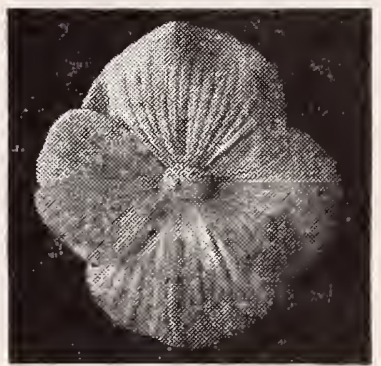

\section{GIANT SINGLE}

Because of the immensity of their huge flat petals and their intense colors, a bed of these presents a dazzling picture. The giant saucer-like flowers are accented by central anthers of pure bright yellow and are a welcome spot of color.

Red, Three \$1.15 - Pink, Three $\$ 1.00 \bullet \quad$ Rose, Three $\$ 1.00$ White, Three \$1.15 - Yellow, Three \$1.15 Mixed Single Begonias, Three $\$ 1.00$, Doz. $\$ 3.50$

\section{PICOTEE CAMELLIA}

This has the same shape as the Camellia-flowered, but is beautifully colored in two-toned combinations. The edges of the petals definitely contrast with the interior.

Mixed Colors only, Three $\$ 1.15$, Doz. $\$ 4.00$

\section{CRISTATA BEGONIAS}

A single type that is only slightly frilled, but which bears a Coxcomb-like tuft or crest on each petal. A very novel form of the Begonia that is interesting if used in floating flower arrangements.

Mixed Colors only, Three $\$ 1.25$, Doz. $\$ 4.00$

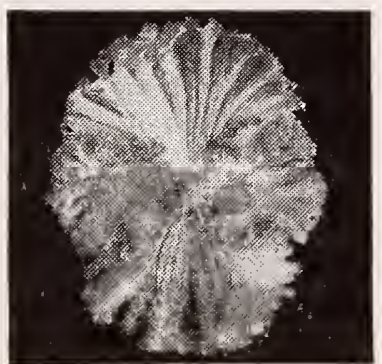

\section{CRISPA BEGONIAS}

This single Begonia has edges so deeply cut and frilled that it looks double. This type is distinguished by flowers of exquisite grace and beauty-more unusual than the other types and particularly de. sirable for decorative arrangements.

Red, Three \$1.15 - Pink, Three $\$ 1.00 \bullet \quad$ Rose, Three $\$ 1.00$ White, Three $\$ 1.00$ Y Yellow, Three $\$ 1.15$ Mixed Crispa Begonias, Three $\$ 1.00$, Doz. $\$ 3.50$

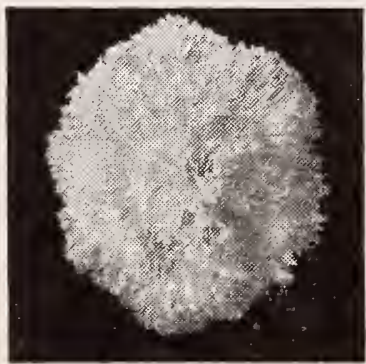

\section{CARNATION FLOWERED}

(Fimbriata Plena)

The formal Carnation-flowered Begonia is an interestingly differ. ent type, having fully double flow. ers with short, deeply serrated and fringed petals that give the mature flower the appearance of a huge Carnation.

Red, Three \$1.00 - Pink, Three $\$ 1.00 \quad$ Rose, Three $\$ 1.00$ White, Three \$1.15 - Yellow, Three $\$ 1.15$ Mixed Carnation-Flowered, Three $\$ 1.00$, Doz. $\$ 3.50$

\section{ROSEBUD BEGONIAS}

A double type of Begonia with flowers of the most exquisite form resembling perfect rosebuds with beautiful tonal pastel shadings.

Mixed Colors only, Three $\$ 1.25$, Doz. $\$ 4.00$

\section{HANGING BASKET BEGONIAS}

This is the Pendula flora plena or Lloydi type, a strain of hanging basket Begonia that contains only double-flowered sorts. Often there are hundreds of blossoms to a bulb. They are also excellent for rock garden work.

Mixed Colors only, Three $\$ 1.35$, Doz. $\$ 4.50$

\section{Named Waxielies}

Autumn Glow An extremely large Cristata type, the tufts or crests of which are a deep copper, contrasting with rest of flower, which is apricot. The flowers sometimes measure ten inches across the bloom. 


\title{
PRIZE WINNERS
}

\author{
Since 1874
}

The Gladiolus of the present are vastly different from the Gladiolus of not many years ago. John Lewis Childs, founder of Flowerfield, was the leader in early improvements in Gladiolus culture.

We are proud to continue to supply largest sized, highest quality bulbs of the best varieties for garden and indoor decoration.

\section{CHOICE VARIETIES}

Abu Hassan A new introduction of dark violet-blue. Grows tall and straight opening up to 8 florets at once. It was a prize winner in Europe when introduced.

Each 50c, Doz. $\$ 5.00$

Algonquin A brilliant light scarlet Gladiolus distinguished by very large florets, and long formal heads, often having 8 or 9 florets open at once up a flower spike as high as 5 feet.

Three 50c, Doz. $\$ 1.75$

Barcarolle Undoubtedly one of the most beautiful orange Gladiolus. Florets are finely ruffled, adding to the value of this most excellent flower. Its clear grenadine orange is a new color for Gladiolus. Three 50c, Doz. $\$ 1.75$

Cubana A deep dark red. This is one of the darkest Gladiolus. The buds are almost black and the florets open to look as if they were rich velvet. This variety is one of the finest we have imported and we know it will be a winner here.

Each 75c, Doz. $\$ 7.50$

Elizabeth the Queen Large ruffled lavender-mauve florets with darker lines in the throat. The ruffled florets make this variety one of the loveliest Gladiolus offered for the garden in a long time.

Three $\$ 1.00$, Doz. $\$ 3.50$

Gelber Herald (Yellow Herald) The color of this new amber-yellow is very pleasing. The wide open florets have a carmine blotch in the throat and are well placed and spaced. Introduced by the originator of Gate of Heaven, it is a real improvement in the yellow Gladiolus.

Each $40 \mathrm{c}$, Doz. $\$ 4.00$

\section{Greta Garko}

The buds and the first opened florets of Flowerfield's Greta Garbo are a very light cream-pink, the flower rapidly becomes rosy white after opening to full size. The florets often measure 6 inches across. Greta Garbo averages more florets to the spike than any other variety grown. The flower spike is carried well above the ground on tall, very strong stalks.

Three $75 \mathrm{c}$, Doz. $\$ 2.50$ 


\section{GLADIOLUS}

Gladiolus are relatively easy to grow, requiring little special attention, and so are a "natural" for all gardens. Because of the excellence of the Gladiolus as a cut flower it is easy to transfer the beauty of the garden into the house.

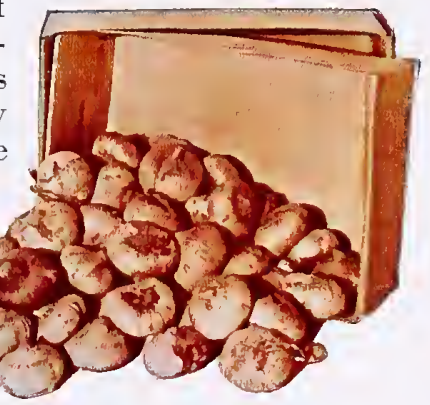

They prefer a sunny location in well-drained soil. Plant 4 to 6 inches deep. For exhibition blooms, feed when planting, again when the foliage is 6 inches high, and finally as the flower buds appear.

\section{FOR COLLECTORS}

High Life The color of this lovely new variety is a clear light blue. The florets open wide and are faced to make it a very excellent show variety. The stems are tall and straight. It is exceptional as a garden variety and as a cut flower.

Each $\$ 2.00$, Doz. $\$ 20.00$

Irak An outstanding "smoky." Large spikes of rose-grey, of silvery tone, hued and mottled with lavender and flame. The unusual coloring is particularly striking in arrangements. Three 50c, Doz. $\$ 1.75$

Leading Lady This pure white sport of Picardy has been outstanding in every Gladiolus show since 1944, and was a consistent winner in the 1946 shows. Leading Lady has all the beauty of form and sturdy lasting qualities of Picardy.

Three $\$ 1.25$, Doz. $\$ 4.00$

Red Ensign Bright scarlet with a white throat. This particular combination of colors is equally pleasing to decorate the garden or the house.

Three 50c, Doz. $\$ 1.75$

Silver Gull One of the best of the new introductions. The color is a silver-bluish gray with a creamy blotch. It will be very popular on the show table as the coloring is novel and very lovely. As many as 8 florets open at one time on tall elegant stems.

Each 60c, Doz. $\$ 6.00$

\section{Manganet Deatom}

Margaret Beaton is one of the best new varieties to appear in recent years. The color is a startling contrast of red and white. It and Leading Lady are the most talked of new Gladiolus of the past few years. Margaret Beaton is particularly lovely for use in flower arrangements where its brightness livens any room.

Three 55c, Doz. $\$ 2.00$ 


\section{DISTINCTIVE VARIETIES FOR}

EXHIBITOR'S COLLECTION 6 Bulbs Each of the Varieties on These 2 Pages 36 Bulbs for $\$ 4.75$ 12 Bulbs Each of These Varieties 72 Bulbs for $\$ 9.25$

Separately Packed and Labeled

Of recently proven merit, these distinctive Gladiolus are the consistent prize winners of their color class, at the Exhibitors' tables in the Flower Shows.

These large flowered varieties are particularly suitable for the borders, especially when planted in groups or colonies of a single color. Their tall and graceful spikes of clear true color will draw immediate attention and provide focal points of beauty when they are in bloom.

Green Light The charm of this variety is its peculiar greenish gloss which overlays the creamy yellow of the large well-formed, slightly ruffled florets. Green Light appears really green in the bud stage.

Three 50c, Doz. $\$ 1.75$

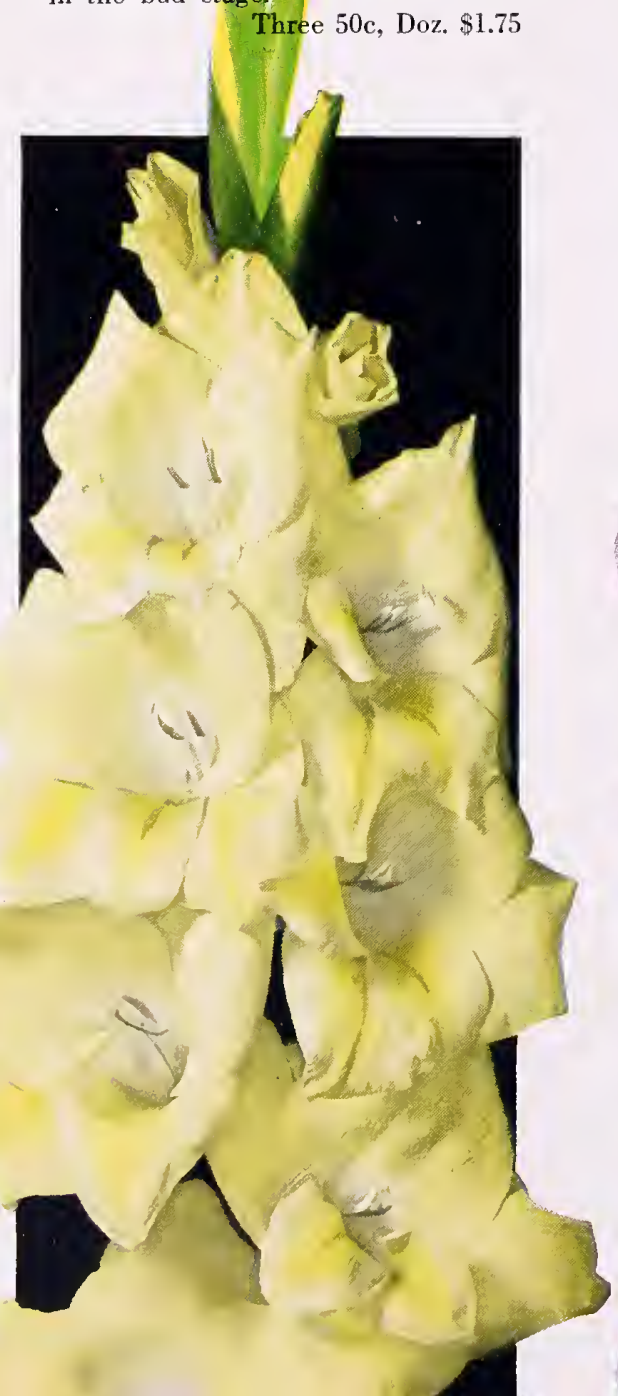

Blue Bequty An excellent variety of light blue with the efges of the floret petals lined in violet-blue. The florets are very large. A really dependable exhibition variety

Doz. $\$ 1.50$

Corona Soft blush-white petals with a lovely pink picoteee edge makes Corona one of the loveliest Gladiolus yet hybridized. The growth characteristics of $\mathrm{Co}$ rona are beyond reptoach

Three 50c, Doz. $\$ 1.75$

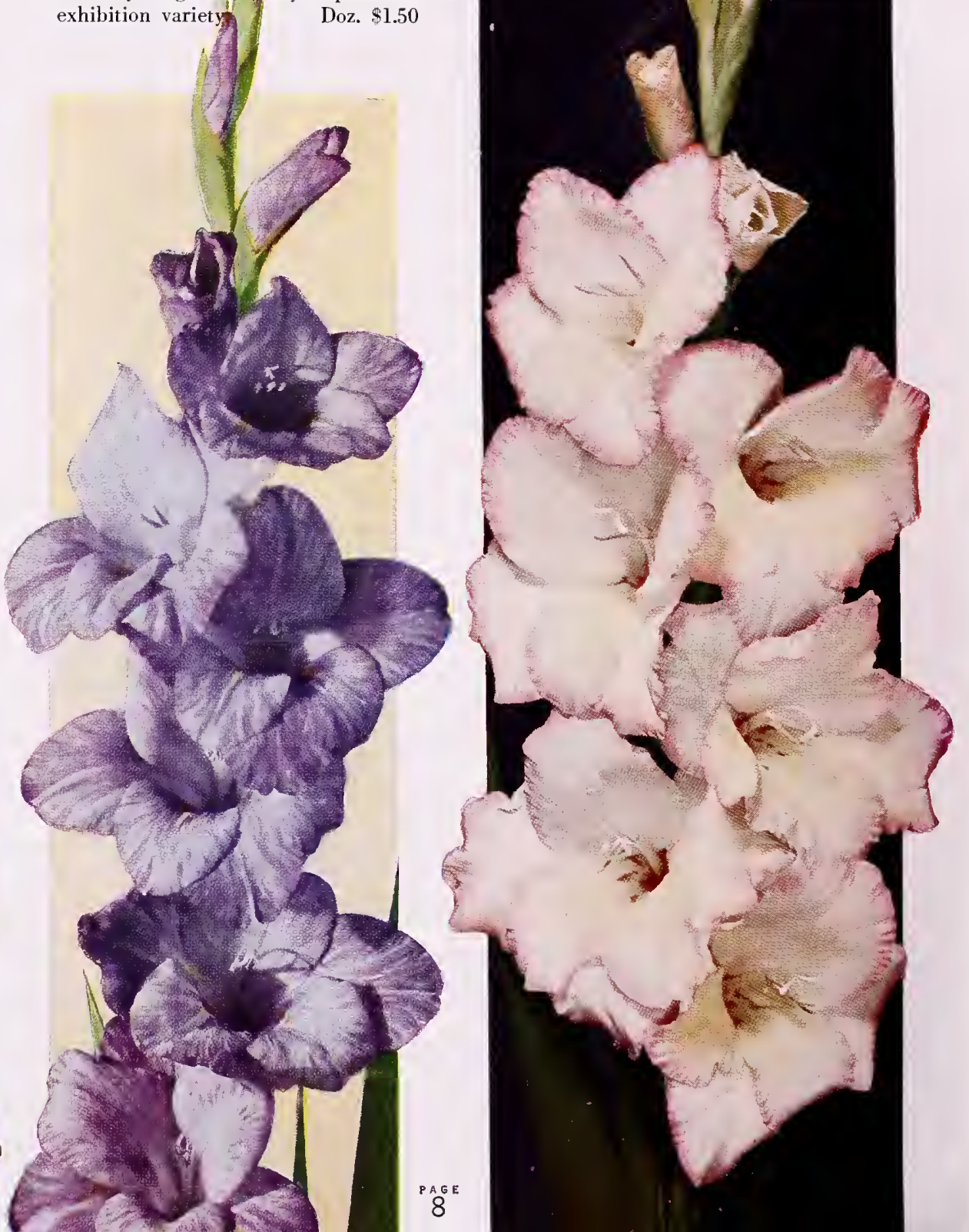




\section{GLADIOLUS}

\section{CONNOISSEURS AND EXHIBITORS}

As a cut flower, the Gladiolus is unsurpassed. The varieties listed here and on the following pages are offered in such a wide choice of color that one could "decorate" either by matching existing color schemes or by heightening them with charming contrasts. For table arrangements or for corsages merely cut with shorter stems.

American Commander In the medium red class, American Commander is one of the newest and best introductions, and has taken the eye of the commercial growers for itorfine color and excellent growing char leristics.

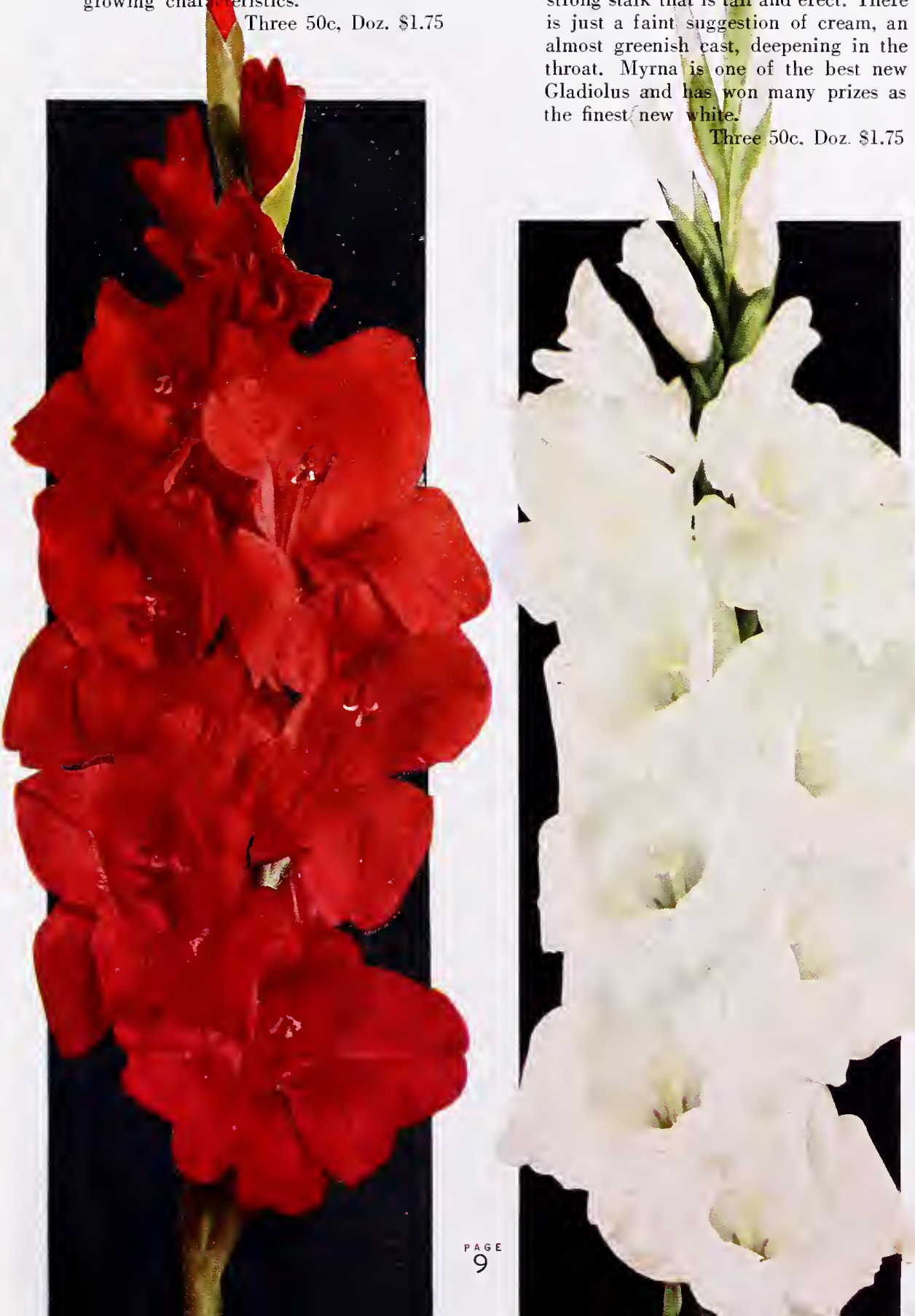

Myrna The huge glistening white florets of Myrna are gracefully placed on a strong stalk that is tall and erect. There is just a faint suggestion of cream, an almost greenish cast, deepening in the throat. Myrna is one of the best new Gladiolus and has won many prizes as the finest new wite.

Three 50c. Doz. $\$ 1.75$ The very finest Gladiolus garnered from this list and new named varieties of which we have too few to list.
Peggy Lou A lovely deep pink Gladiolus of almost perfect form and substance. The florets are large and of fine texture, standing up well as a cut flower. Peggy Lou is sturdy with a tall, thick, strong spike to hold its long flower head firmly. Doz. $\$ 1.50$

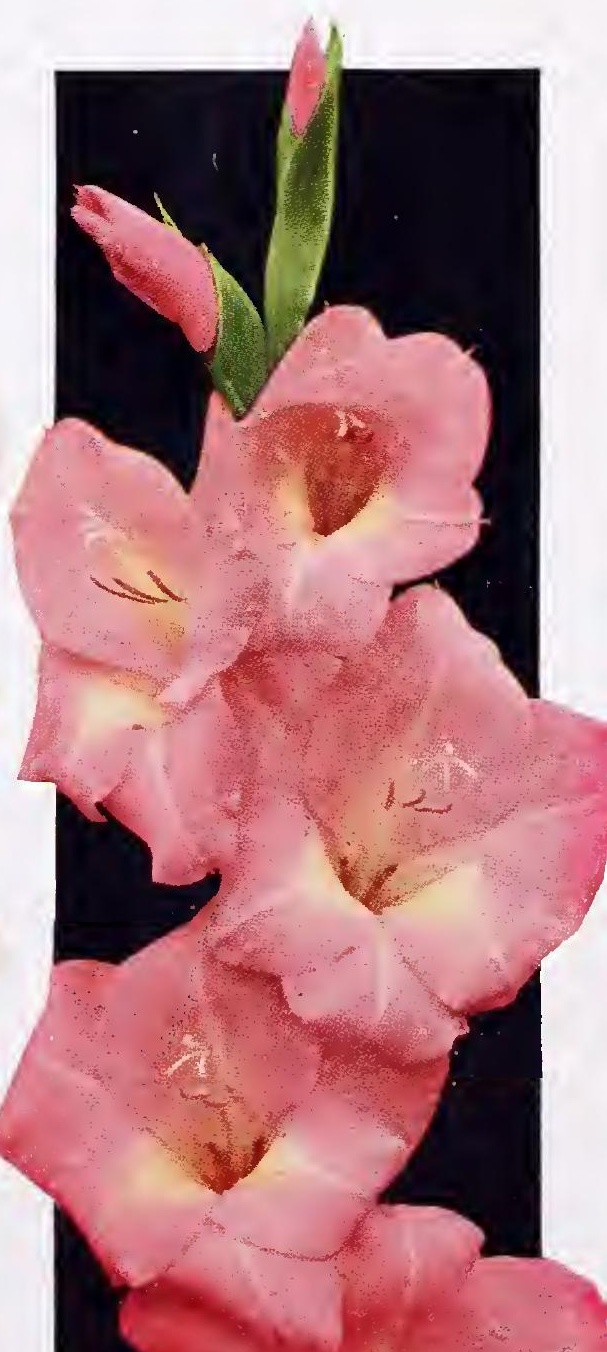




\section{"GARDEN CHAMPIONS"}

\section{MEDIUM PRICED GLADIOLUS IN ITS COLOR RANGE}

Rewi Fallu Huge and red, this Gladiolus is another of the New Zealand varieties so well known for their tremendous size and extraordinary vigor. Named for its Maori hybridizer, Rewi Fallu is one of the finest dark reds known. Even the very topmost bud opens into a flower of very large size.

Doz. $\$ 1.50$

Rosa Van Lima Tall straight spikes of a light rosy pink with a touch of darker shading in the throat. Large wide flowers, opening seven to eight at a time.

Doz. $\$ 1.50$

Silentium White with throat blotch of carmine. An exceptional cut flower. Florets perfectly placed on tall spikes. Early bloomer.

Three 50c, Doz. $\$ 1.75$

:Surfside This splendid Gladiolus continues to enjoy great popularity. Beautiful ruffed white with a fine line of lavender in the throat. An easily grown variety.

Doz. $\$ 1.25$

Takina The largest Gladiolus listed. It has been exhibited with florets measuring $83 / 4$ inches across, 9 open at a time and grown to a height of over 6 feet. Takina is a beautiful lilac-purple.

Three 50c, Doz. $\$ 1.75$

:Vagabond Prince One of the most striking Gladiolus for cut flower arrangements that has vet been hybridized. Vagabond Prince has a deep mahogany color, livened by a garnet shield in the throat and across the petals. Strong, sturdy and straight, carrying many florets open at a time.

Doz. $\$ 1.50$

\section{Marked Varieties Not Pictured}

Unusual and scarce varieties not pictured. All prize winners at the show tables. The vivid colorings of these varieties are seldom associated with garden Gladiolus.

\section{Each of 5 Starred Varieties • 30 Bullbs $\$ 4.00$}

Each Variety Separately Packed and Labeled 


\section{Flowerfield's THREE MOST POPULAR GLADIOLUS}

Picardy, Wanda and Maid of Orleans are the three most popular Gladiolus at Flowerfield. And deservedly so, because they are really top-notch performers in the garden, long lasting when cut, and the bulbs store easily and well over winter. Judging from our orders, these are the ones that most people want, especially for cut flower purposes.

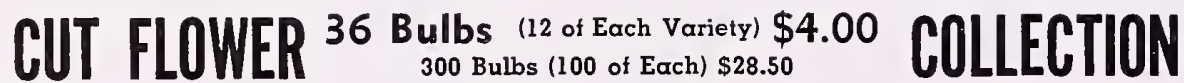

EACH VARIETY SEPARATELY PACKED AND LABELED

Picardy The most popular of all Gladiolus, a lovely pink that is exhibited everywhere, in Flower Show fter Flower Show, and in every florist's window. Flowerfield's huge healthy bulbs produce the finest Gladiolus for your garden. This is a superb variety whose spike is always straight, erect and carries many florets open at a time.

Doz. $\$ 150,50$ for $\$ 5.50,100$ for $\$ 10.00$

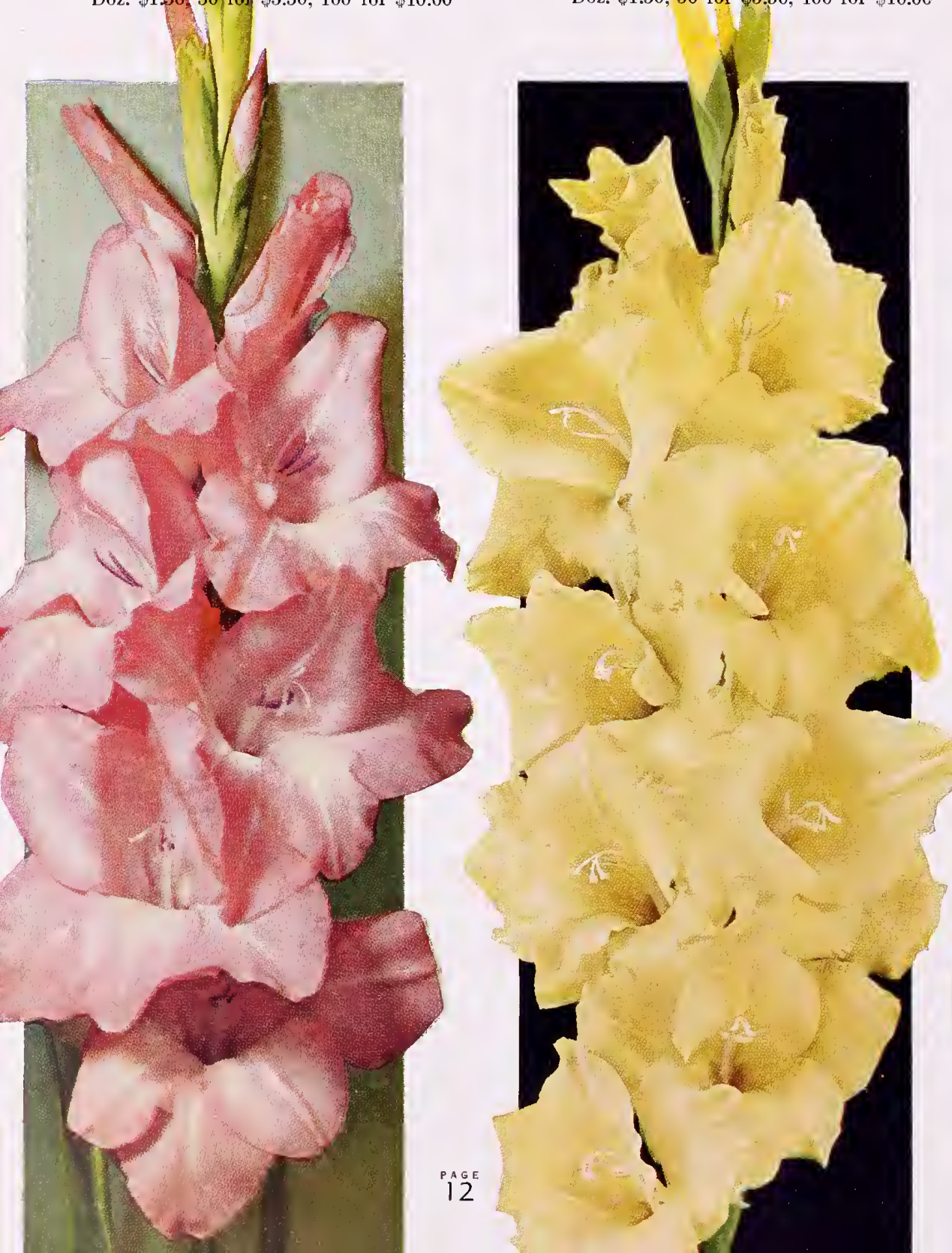

Wanda Found in a field of Picardy, Wanda is a sport of that sturdiest of all Gladiolus. Its lovely cream-yellow makes it one of the most useful and beautiful in the garden or the cut flower bowl. Wanda is doubly welcome since it is the first satisfactory largeflowered yellow Gladiolus and one of the finest ever introduced.

Doz. $\$ 1.50,50$ for $\$ 5.50,100$ for $\$ 10.00$

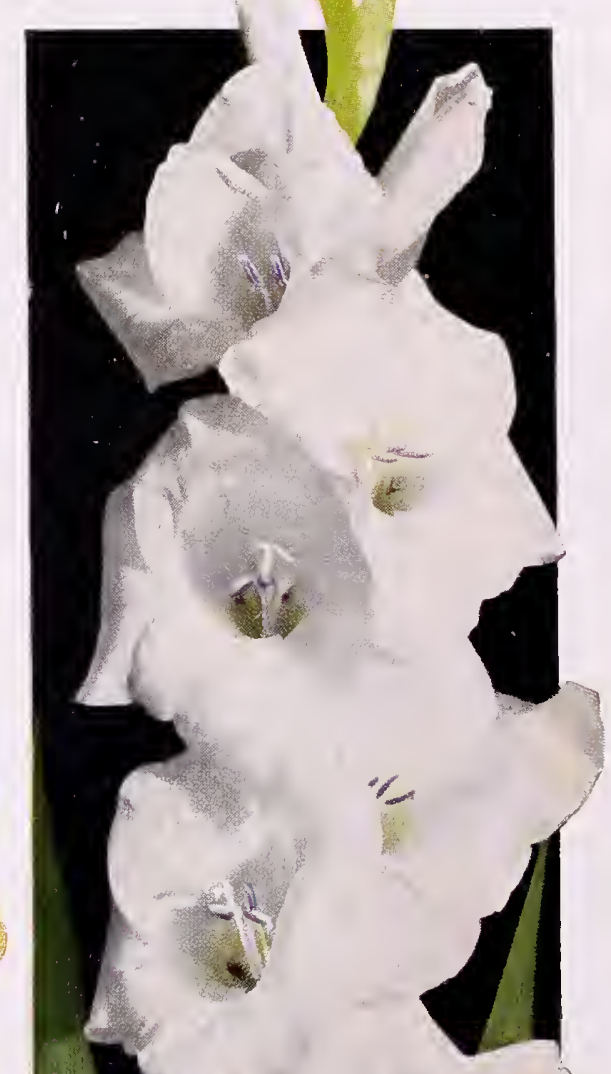

Maid of Orleans This is a fine all-around white. A soft cream shade in the center tends to turn pure white on the outer edges of the petals. The florets are well shaped and particularly well arranged on the long flower head. This variety is long lasting when cut, ideal for arrangements.

Doz. $\$ 1.50,50$ for $\$ 5.50,100$ for $\$ 10.00$ 


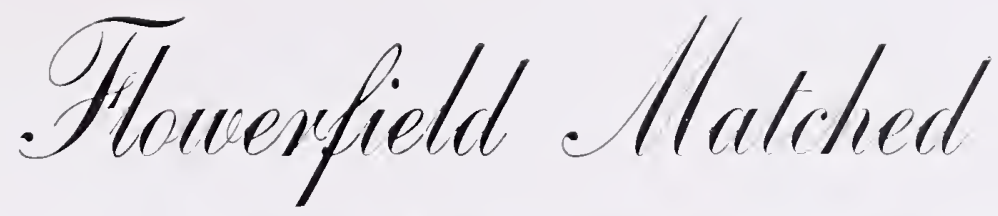

Flowerfield's Matched Mates have been inspired by the beauty inherent in all bulbs. The stately flower spike of the Gladiolus and majestic globular head of the Dahlia create an artistic complement and balance. Flowerfield's Matched Mates are a combination of Dahlias and Gladiolus whose matchings are exactly alike in tone and color.

Matched Mates should be planted together, they will grow together, bloom together and, in flower arrangements, complement each other. The Gladiolus in these perfectly matched beauties should not be planted until mid-June for blooms in September when Dahlias are at their best. 10 Gladiolus to each Dahlia is recommended.

\section{WHITE MATCHED MATES}

Snowsprite Unquestionably one of the best miniature Dahlias. Artistically shaper, glistening snow-white blooms are held boldly on perfect stems.

Each $75 c$

Snow Princess Clear white with a light cream throat. Florets are of heavy texture and open many at a time. Tall growing. One of the better recent introductions of white Gladiolus.

Ten $\$ 1.50$

\section{Dahlia, 10 Gladiolus $\$ 2.00$}

\section{PINK MATCHED MATES}

Elizabeth Pape The best and most artistic miniature Cactus Dahlia. Its cream heart and nicely whorled pink petals give it an unusual distinction.

Each $75 c$

Picardy A four-star pink Glad. One of the best flowers ever hybridized. The cream throat sets off its lovely pink petals as in its matched mate.

Ten $\$ 1.25$

\section{Dahlia, 10 Gladiolus $\$ 1.75$}

\section{YELLOW MATCHED MATES}

Frau O. Bracht A clear primrose-yellow semi-cactus Dahlia. It is a very popular, profusely growing variety, often regarded as a Cactus type.

Each $75 c$

Gate of Heaven A fine bright yellow Gladiolus with wellspaced, ruffled florets.

1 Dahlia, 10 Gladiolus $\$ 1.75$

Ten $\$ 1.25$

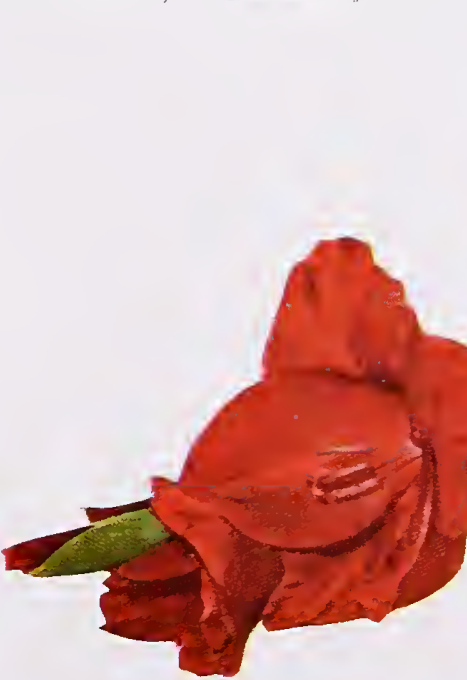

GLADIOLUS AMERICAN COMMANDER

Ten $\$ 1.25$

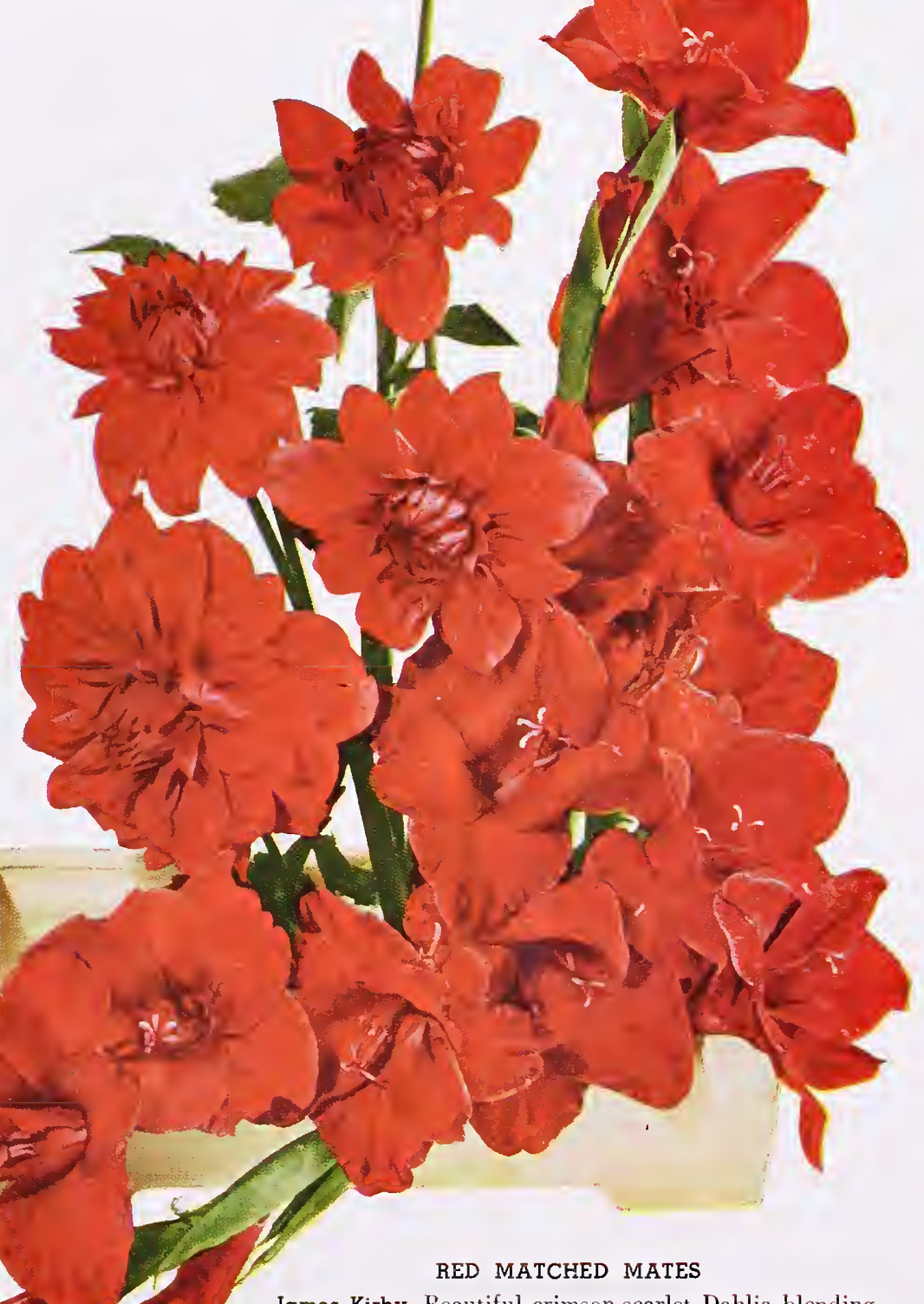

James Kirby Beautiful crimson-scarlet Dahlia blending to ruby tones at the center. The stems are tall and straight. It makes an excellent cut flower. Each 50c American Commander A fine dark scarlet-red without any markings. A sturdy consistent grower which has made a great name for itself.

1 Dahlia, 10 Gladiolus $\$ 1.65$
Ten $\$ 1.40$ 


\section{GIANT DAHLIAS}

The following listings of fine Dahlias contain only named varieties of the highest Flowerfield quality.

\section{SYMBOLS INDICATE TYPES OF BLOOM}

FD (Formal Decorative)

ID (Informal Decorative)

SC (Semi-Cactus)

C (Cactus)

Mrs. W. S. Knudsen ID A beautiful glistening white flower that blooms in profusion on strong sturdy plants. One of the best Dahlias. Each $\$ 1.00$

Oakleigh Monarch ID A beautiful large dark red Dahlia. The plant is sturdy and strong, contrasting with the deep garnet of the decorative blooms.

Each $\$ 1.25$

Sagamore FD Large flowers of orange suffused with red, creating an effect of bronze. Robust grower, very tall.

Each 75 c, Doz. $\$ 7.50$

Son of Satan SC This is an improvement over Satan as it is a bright scarlet and has stronger stems. Although the petals revolute suffciently to bring it into the Incurved Cactus Class, under varied conditions it will develop into a Semi-Cactus. Blooms 11 by 5 inches.

Each $\$ 1.00$

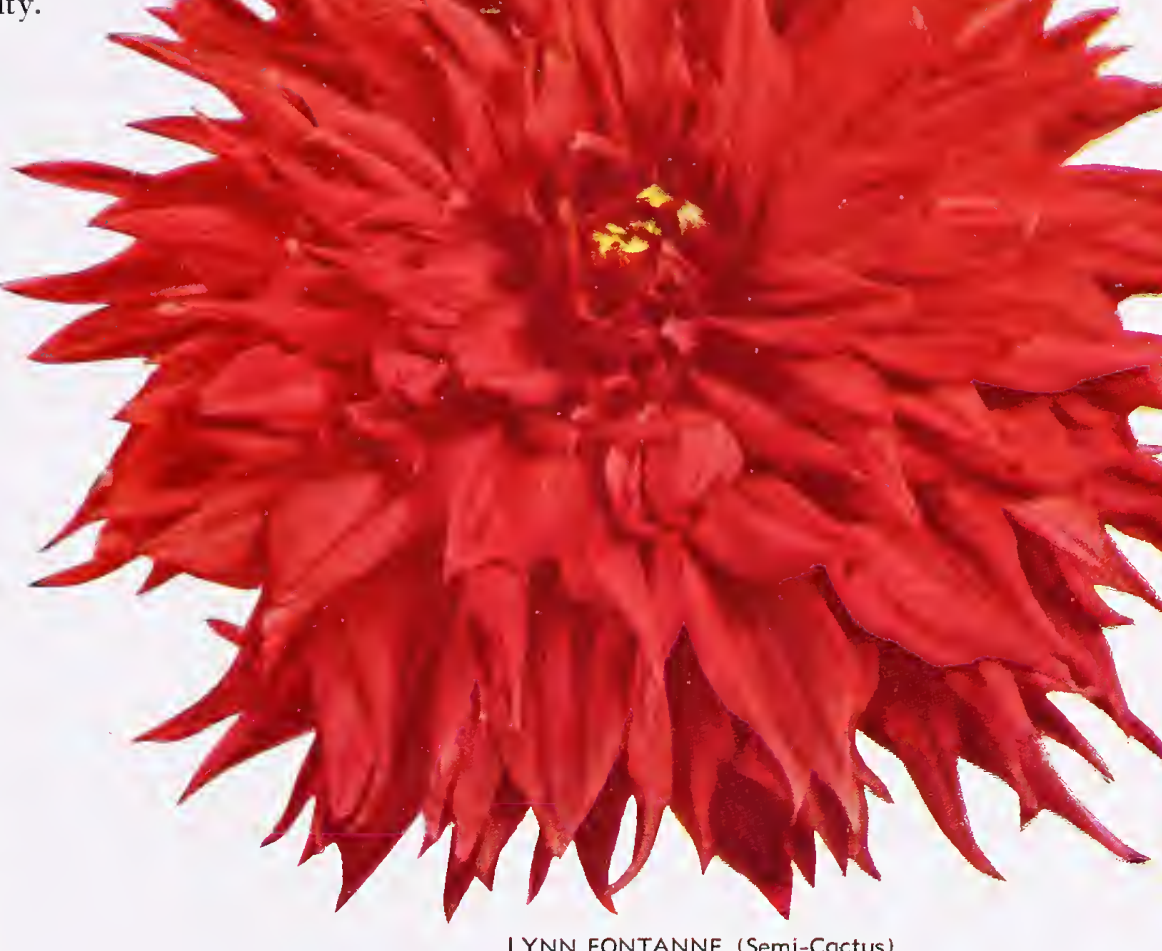

Sunrays ID An unusual color; clear buff, hued apricot, with a distinct peach-red on the reverse of the petals. Flowers are large and plentiful, covering the plant. A leader among the new popular varieties. Each $\$ 1.00$

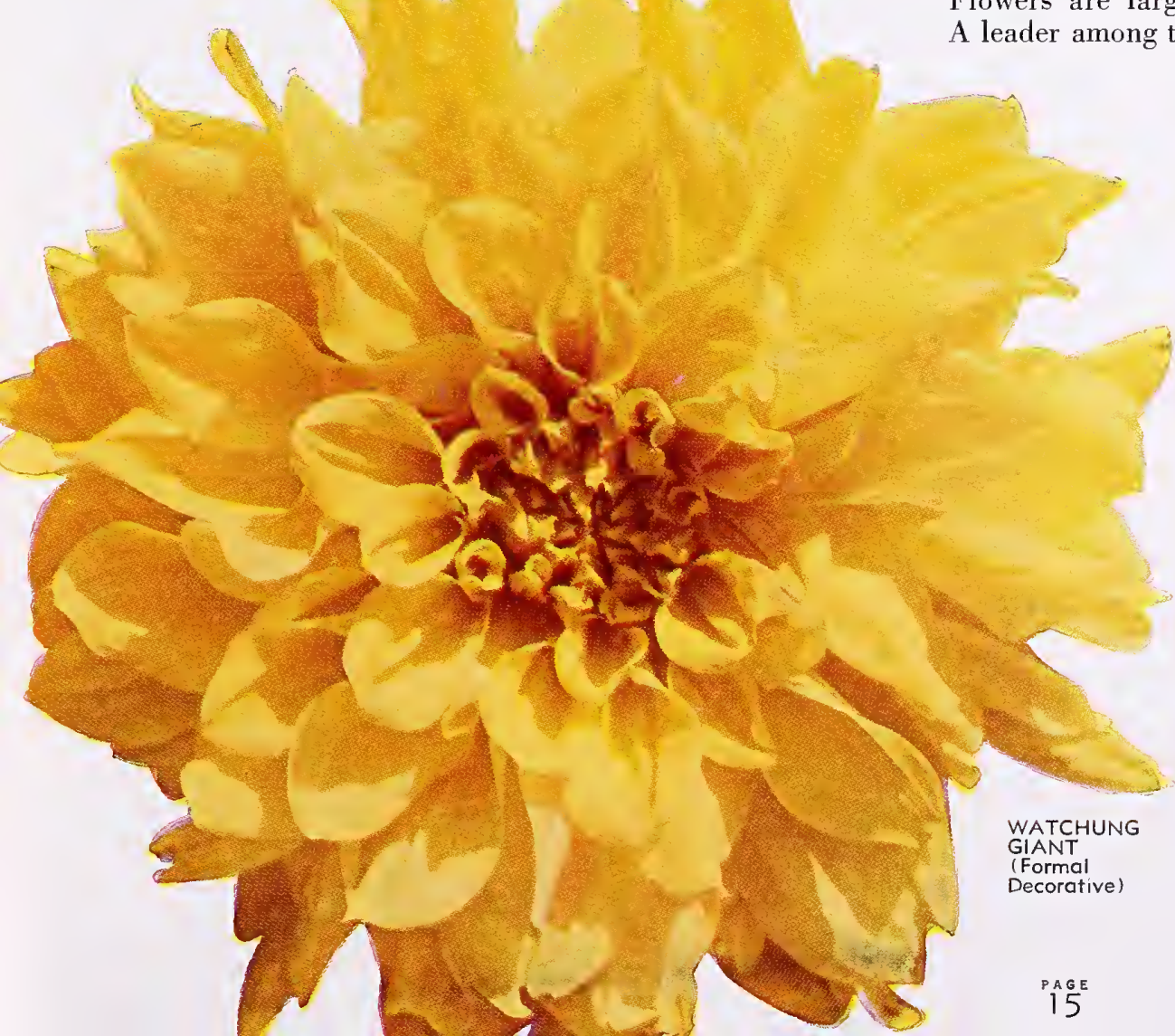

Watchung Giant ID Deep amber-yellow suffused orange-cadmium. Grows to tall bushy plants and produces an abundance of large flowers that are beautiful in the garden or for cutting. Illustrated.

Each 75c. Doz. $\$ 7.50$

White King FD A standard white variety. The blooms are very perfect in their formation and are excellent cut flowers. Illus. trated. Each 40c, Doz. $\$ 4.00$

\section{POPULAR}

\section{DAHLIA COLLECTION}

Watchung Giant El Toreador

Jersey's Bequty

White King

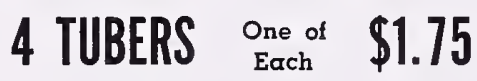




\section{en POMPON DAHLIAS}

\section{Tom Flowerield}

Flowers unsurpassed for perfection in form, blooming in a variety of pure and blended colors, making them the little beauties of the Dahlias. Grow them for garden effect, cut them for house decoration. You will find these bushy plants hard to beat. Pompon Dahlias grow thirty inches tall, and are particularly desirable because the more you cut, the more they will bloom.

\section{COLLECTION}

One each of the pictured varieties.

6 Tubers, \$1.95

Separately Labeled

Amber Queen Button-like blooms of amber, shaded to apricot, carried well above the dark foliage of the plant.

Each 30c, Doz. $\$ 3.00$

JOHNNY PEPPIN EDITH MUELLER
MARY MUNNS AMBER QUEEN JOE FETTE
ROSE OF WILMOTH

\section{SINGLE DAHLIAS}

Charmingly simple, exquisitely colored, Single Dahlias are one of the finest of garden plants. They require no staking and may be used with fine effect in the mixed border. Long lasting, unsurpassed as a cut flower, beautiful in the garden.

Pink Lassie Pale pink single flowers of enormous size. Free flowering and fine for cutting.

Each $75 c$

Pequot Yellow $\Lambda$ 5-inch broad-petaled flower of clear yellow, graceful, on a strong wiry stem. Unsurpassed for exhibition. Height 3 feet.

Each $50 \mathrm{c}$

Snow White A pure white bloom with serrated petals 5 inches across. Its dclicate beauty makes Snow White worthy of its name. It grows robustly and as a cut flower has wonderful keeping qualities. Height 4. feet. Pot plants only, no tubers available.

Each 75c

Edith Mueller A bright soft apricot, suffused peach-red. Much in demand as a cut flower. Each 35c, Doz. $\$ 3.50$

Indian Chief Bright red petals tipped with white. It blooms very freely and continuously, and is unexcelled for cutting.

Each 35c, Doz. $\$ 3.50$

Joe Fette Its pure white bloom is unsurpassed. Its long stems make it a perfect flower for cutting.

Each 35c, Doz. $\$ 3.50$

Johnny Peppin Excellent deep red. The center is very dark as the flower opens.

Each 35c, Doz. $\$ 3.50$

Mary Munns A mallow-purple bloom growing on a long stem, producing flowers of high merit.

Each 40 c, Doz. $\$ 4.00$

Morning Mist A pleasing combination of lavender and white. Flowers are exceptionally tight in formation.

Each 30c, Doz. $\$ 3.00$

Rose of Wilmoth Soft rose-pink flowers of uniform size.

Each 40c, Doz. $\$ 4.00$

Sunny Daybreak Perfect flowers of canary-yellow, tipped with red. Creates a color combination unexcelled.

Each $40 \mathrm{c}$, Doz. $\$ 4.00$

\section{MIXED POMPONS}

An assortment of different colors from these and other varieties.

\section{TUBERS $\$ 1.50$}




\section{MINIATURE DAHLIAS}

Dwarf bushy plants that require no staking, disbudding or fussing, which give you week after week, a constant supply of little Dahlias which, in everything except size, reproduce all the beauty of the giant prize-winning blooms of the big Dahlia shows. The stocky plants, 2 to 4 feet tall, a good size for the mixed flower border.
The greatest advantage of these Miniatures is their easy culture and their "cut-and-come-again" quality. The more you cut them the better they like it. If you haven't yet tried any Miniatures, include a few in your next order, and take our word for it that you will be more than delighted with them. even if you don't care for ordinary Dahlias.

MFD, Miniature Formal Decorative; MID, Miniature Informal Decorative; MSC. Miniature Semi-Cactus; MC. Miniature Cactus; MP, Miniature Peony Flowered.

Andries Orange MSC A bright orange flower of an exceptionally clear, attractive tone, growing on perfectly straight stems. They make a beautiful display.

Each 75c, Doz. $\$ 7.50$

Bishop of Llandatt MIP An unusual and very attractive flower of bright scarlet with a deep garnet center. The lacy foliage is a special feature of this variety, being a beautiful reddish bronze color which makes it stand out in any planting. Highly popular. Each $75 \mathrm{c}$, Doz. $\$ 7.50$

Corinna MFD Pure bright yellow to brighten your garden or your flower arrangements. Of fine form and substance.

Each 50c, Doz. $\$ 5.00$

\section{MIXED MINIATURES}

Splendid assortment of these and other fine Miniature Dahlias.

\section{Three $\$ 1.25$}

D 0z. $\$ 4.50$
Elizabeth Pape MC The best and most artistic pink Miniature Cactus. Its cream heart and nicely whorled pink petals give it a distinction achieved by few.

Each 75c, Doz. $\$ 7.50$

Fairy MFD An early and continuous bloomer of soft violet-rose, shading mauve at the tips. Its form is perfect and its keeping qualities are exceptional.

Each 50c, Doz. $\$ 5.00$

Lady Mary Hope MFD One of the nicest bicolor Dahlias we grow. Flowers are perfectly formed and a pleasing combination of light orange and white. The plants are bushy and compact, growing about two feet. Each 50c, Doz. $\$ 5.00$

Red Head MFD Small fiery scarlet blooms on long stems. The color is a brilliant shade of red not usually seen.

Each 75c, Doz. $\$ 7.50$
Rosalie White MFD A most pleasing bicolor that has become very popular. This little gem is white with broad clean-cut bands of deep rose on the edges of the petals, leaving the tips white. Plants medium tall, with blooms held erect on good stiff stems.

Each 75c, Doz. $\$ 7.50$

Snowsprite MSC Artistic glistening snowwhite flowers. One of the best miniatures grown. Blooms are of fine form and held above the foliage. Each 75 c, Doz. $\$ 7.50$

Sylvia MFD Deep carmine blooms that are symmetrically perfect in form. A bright cheery spot of color in the garden.

Each 50c, Doz. $\$ 5.00$

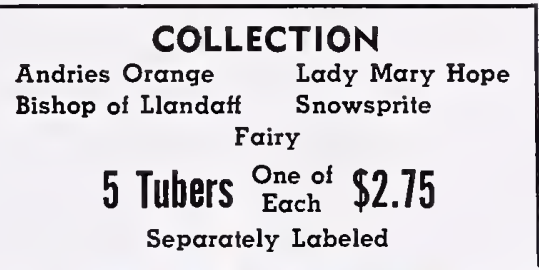

CORINNA

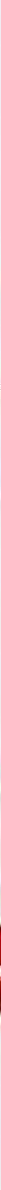





\section{NEW Lom}

City of Portland A beautiful new medium high Canna with deep rich silvery pink flowers above green foliage. Excellent garden subject.

Each 25c, 3 for 70c, Doz. $\$ 2.50$

Eureka The finest white variety of Canna. Dark green foliage topped with large trusses of cream-white flowers. A fine lowgrowing variety adapted to bedding use.

Each $25 \mathrm{c}, 3$ for $70 \mathrm{c}$, Doz. $\$ 2.50$

Hungaria The best known rosy pink, this low growing variety combines beautifully with pink Geraniums for long blooming pastel display.

Each 25c, 3 for 70c, Doz. $\$ 2.50$

Indiana Bright orange flowers on tall plants. Foliage is rich dark green. The brightness of this variety makes it exceptionally desirable.

Each $25 c, 3$ for $70 c$, Doz. $\$ 2.50$

King Humbert Brilliant orange-scarlet flowers with bright markings has made King Humbert a favorite of long standing. Foliage is coppery bronze. Used against a background of evergreens these striking plants with vivid flowers and colorful foliage are very effective.

Each 20 c, 3 for $55 c$, Doz. $\$ 2.00$

King Midas A pure rich yellow flower mounted on vivid green foliage. Grows to $4 \mathrm{feet}$, and forms a lovely contrast in the garden.
Each $25 \mathrm{c}, 3$ for $70 \mathrm{c}$. Doz. $\$ 2.50$

\section{CANNAS}

Louis Cayeux A fine new Canna that has caused much favorable comment wherever seen. The flower heads are a beautiful shade of rose-pink and surmount soft light green foliage. A very effective plant.

Each $35 c, 3$ for $\$ 1.00$, Doz. $\$ 3.50$

Madame Crozy An unusual low growing flower of bright scarlet, neatly edged with a $1 / 4$-inch band of bright yellow that is excellent as an unusual type for borders.

Each $35 c, 3$ for $\$ 1.00$, Doz. $\$ 3.50$

Richard Wallace Canary-yellow flowers on bright green foliage, $3^{1 / 2}$ feet tall. This variety is more prolific than the others.

Each 20c, 3 for 55c, Doz. $\$ 2.00$

The Ambassador This beautiful rich Cherry-red flower has deep bronze foliage. An excellent variety of medium height.

Each 30c, 3 for 85c, Doz. $\$ 3.00$

The President The outstanding Canna. It has immense trusses of fiery red flowers, produced in great profusion. The foliage is very bright green, contrasting sharply with the brilliant heads, making a most impressive display; of medium height.

Each 25c, 3 for $70 c$, Doz. $\$ 2.50$

\section{NOT FUSSY ABOUT SOIL}

Cannas may be planted in almost any kind of soil but prefer a rather heavy soil, where they should be planted 3 to 4 inches deep. They may be allowed to stay in the ground in the autumn as long as they continue to grow and should be left until the tops are touched by the frost. They may then be dug and stored for the winter. Our Canna list is complete. From it you may choose the height, color of bloom and color of foliage which you desire.

\section{CANNA COLLECTION}

\section{Hungaria}

Richard Wallace

8 CANNAS
The President

King Humbert

Two
of Each 1.65

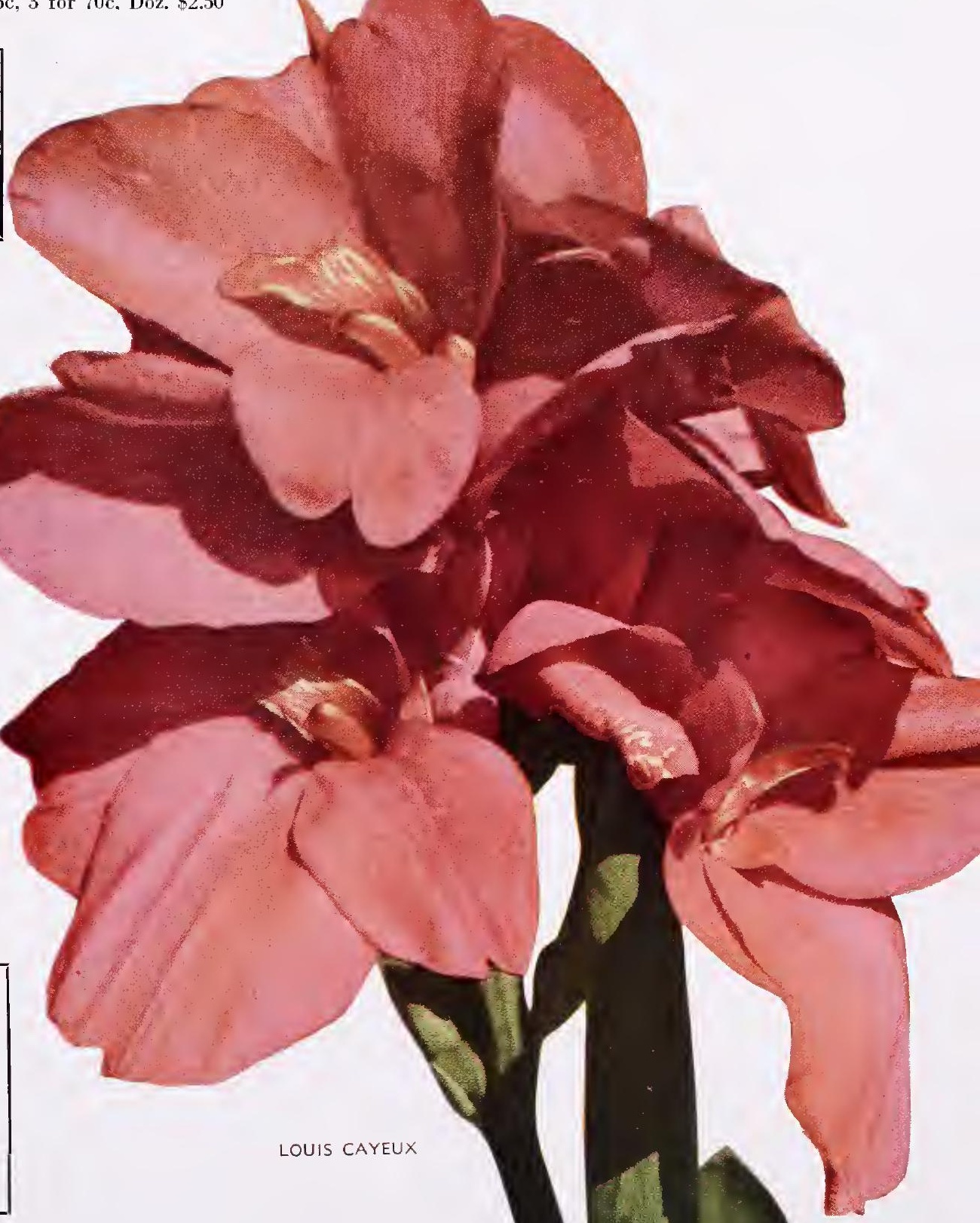




\section{Flowerfield's AMARYLLIS}

Amaryllis are useful subjects for either garden or indoor growing. Few plants can equal the size and beauty of the various Amaryllis. For indoor growing, they are by far the most colorful and easiest to grow. For outdoors, they provide a brilliant color accent.

\section{GIANT HYBRID AMARYLLIS}

Few bulbs give the gardener more for his time and money than the Amaryllis. The hybrids are the finest race of Amaryllis in cultivation. Their diversity of color and markings in a graceful trumpet flower is an excel. lent addition to any garden. Several large blooms to the stalk.

\section{JUMBO BULBS}

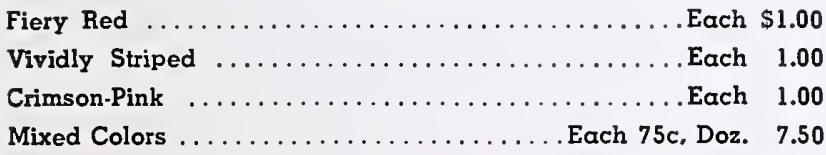

\section{AMARYLLIS FORMOSISSIMA}

(Jacobean Lily)

A fine semi-hardy bulb, producing brilliant scarlet flowers of almost butterfly shape and formation. Easily grown in the house or the low border. They multiply rapidly, forming fine clumps. This fine unusual flower will lend a brilliant splash of color in the border. Blooms in June outdoors.

Large bulbs, Each 50c, Doz. $\$ 5.00$

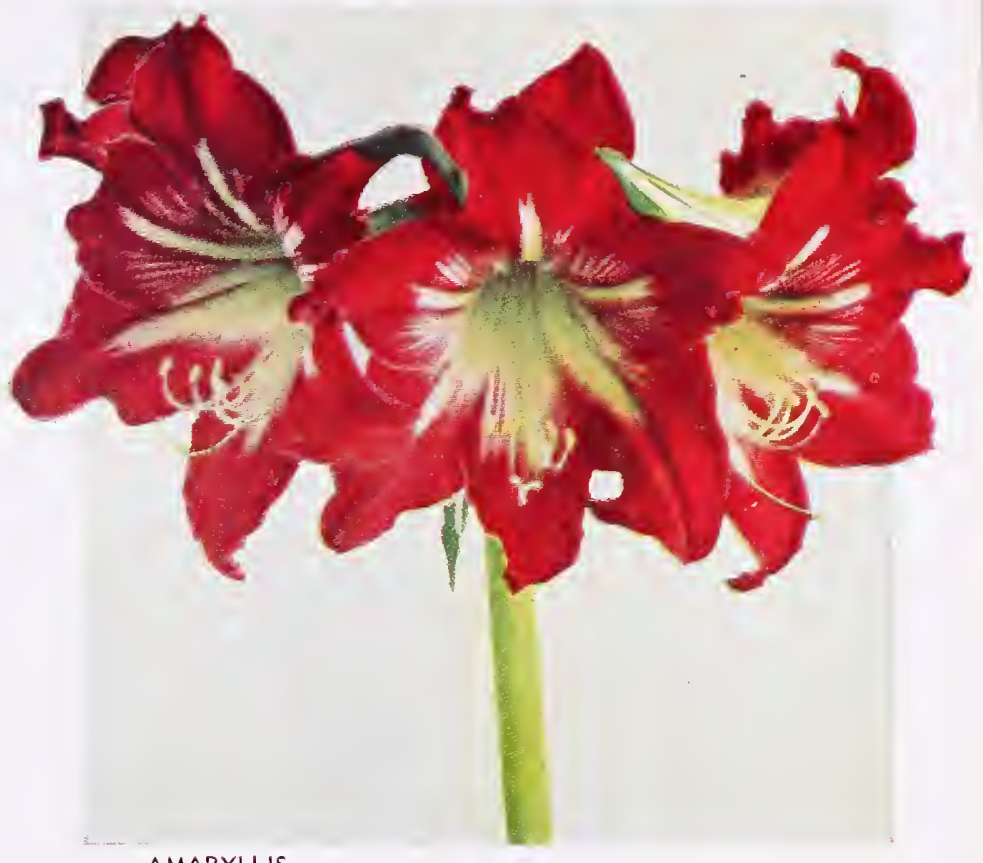

AMARYLLIS

\section{AMARCRINUM}

The finest new bulb hybrid to appear in recent years. The Amarcrinum, a cross between Amaryllis Belladonna and Crinum Moorei, has the appearance of a mammoth Amaryllis, but its color is an even frosty pink. Great trusses are borne proudly aloft on 4 -foot stems. This American creation won the coveted Cory Cup of the Royal Horticultural Society of Great Britain. This amazing flower has an attractive scent, similar to that of the famous Dutch Hyacinth. Blooms outdoors in September and October. Monster bulbs, Each $\$ 3.50$, Doz. $\$ 35.00$

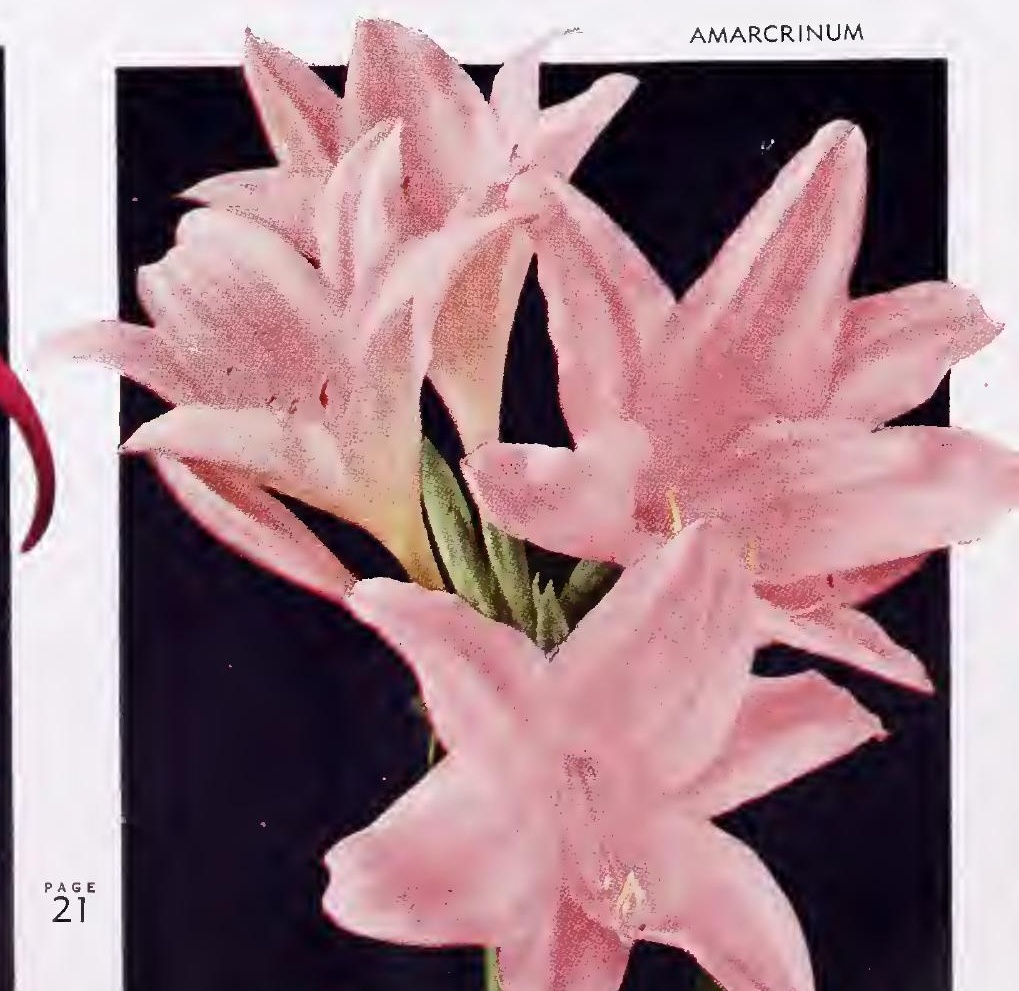




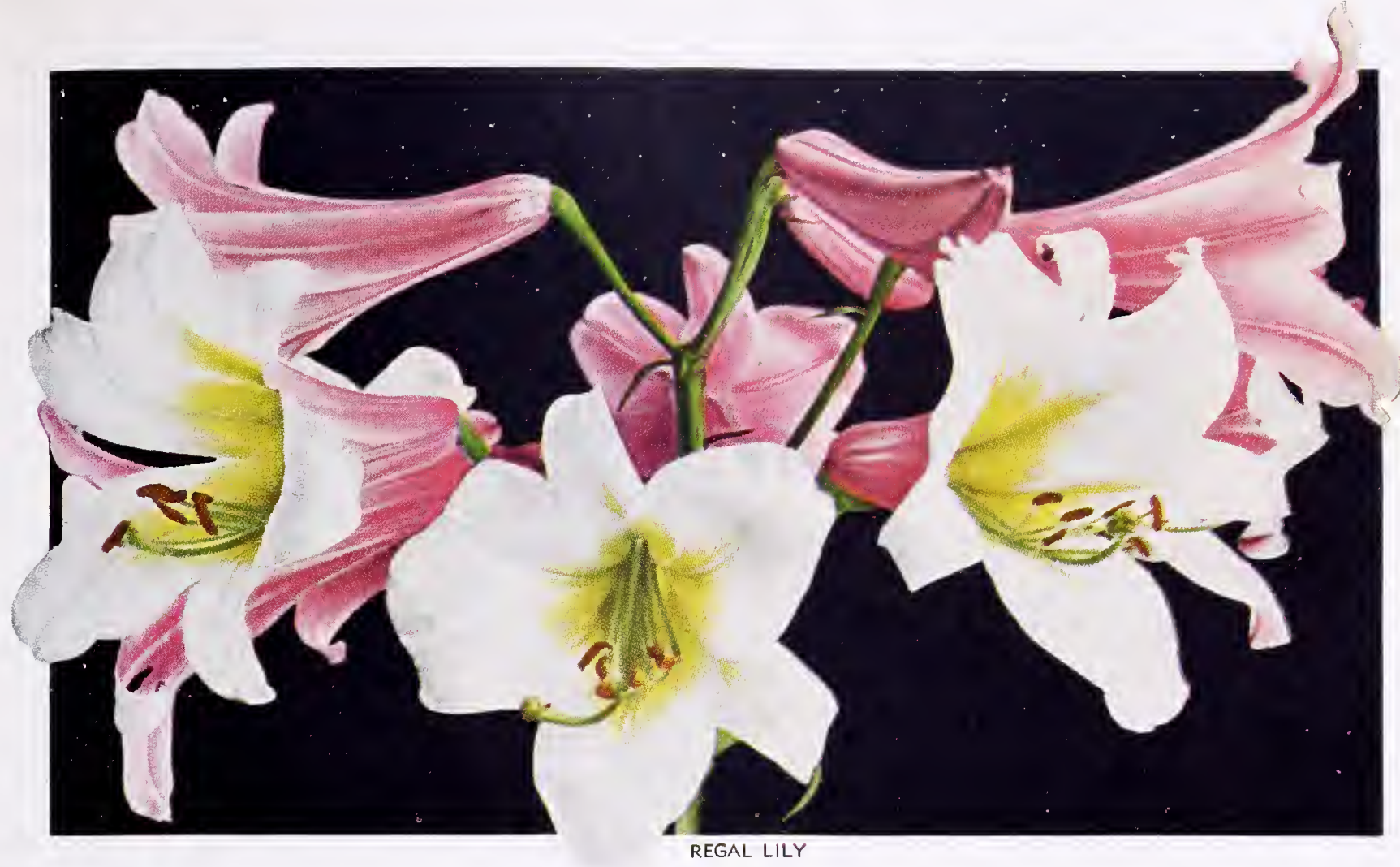

\section{Flowerfield's HARDY LILIES}

\section{REGAL LILY}

Of all the Hardy Lilies the Regal is perhaps the most satisfactory. It is showy in the garden and yet easily grown. The tall stalks, 4 to 5 feet high, are topped by trumpet-like flowers that are pure white inside and tinged with rose outside. The Regal Lily is very floriferous, a single established bulb bearing as many as 20 flowers during the blooming season in July. A stem rooting Lily, the bulbs should be planted deep. allowing $3 \frac{1}{2}$ times the size to cover the bulb. Each $50 \mathrm{c}$, Doz. $\$ 5.00$

\section{LILIUM SPECIOSUM}

The best known and best liked of the recurved type of garden Lilies. The tall, sturdy 4- to 5-foot plants carry well-branched sprays of delicately scented flowers of cream-pink with a light edge and vivid crimson speckles. They flower in August and September.

As Speciosum Lilies are stem-rooting, they must be planted 9 inches or more deep in soil of good drainage. They should be planted near ground-shading plants, as this Lily dearly loves to have its roots shaded.

Each $\$ 1.00$, Doz. $\$ 10.00$

\section{LILIUM HENRYI}

A beautiful and stately Lily growing from 4 to 6 feet in height. The strong stems carry six or more nodding flowers of recurving shape (similar to the Speciosums) and are of a soft orange color with emerald-green hearts. Lilium Henryi should be planted where it is somewhat shaded (just inside of the shrubbery border would be ideal). As this variety is stem-rooting, it should be planted to a depth of 10 to 12 inches. Dependable and healthy, it will be enjoyed for many, manv years. Lilium Henryi blooms in August. Each 75c, Doz. $\$ 7.50$

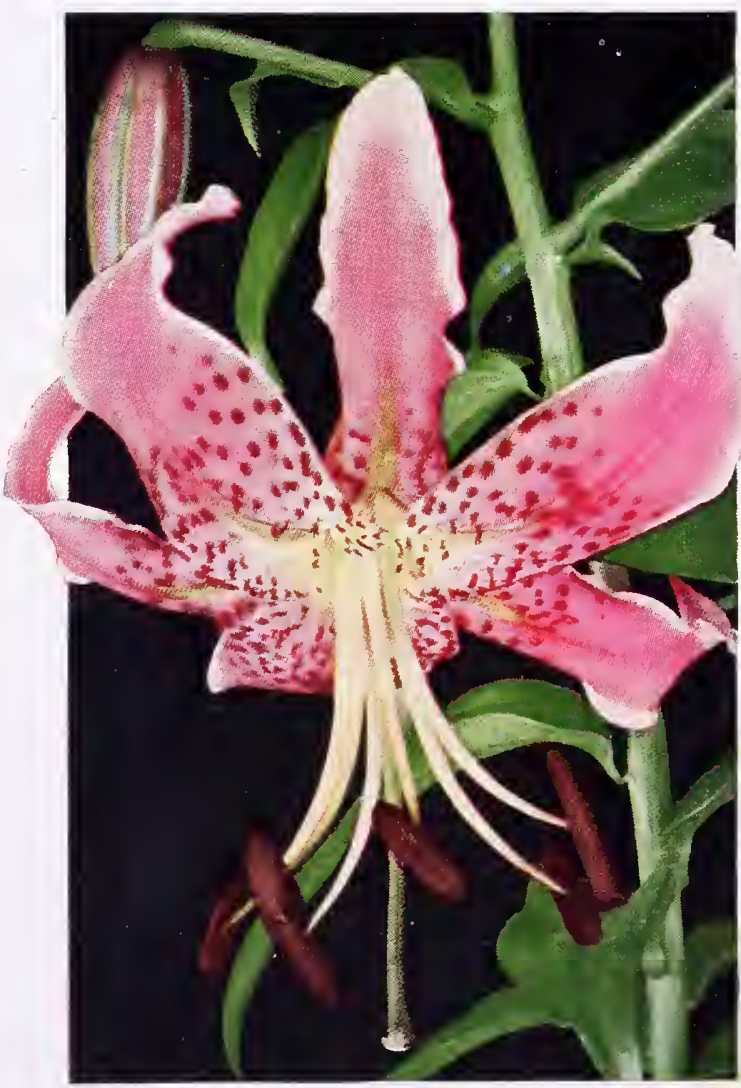

LILIUM SPECIOSUM MAGNIFICUM 






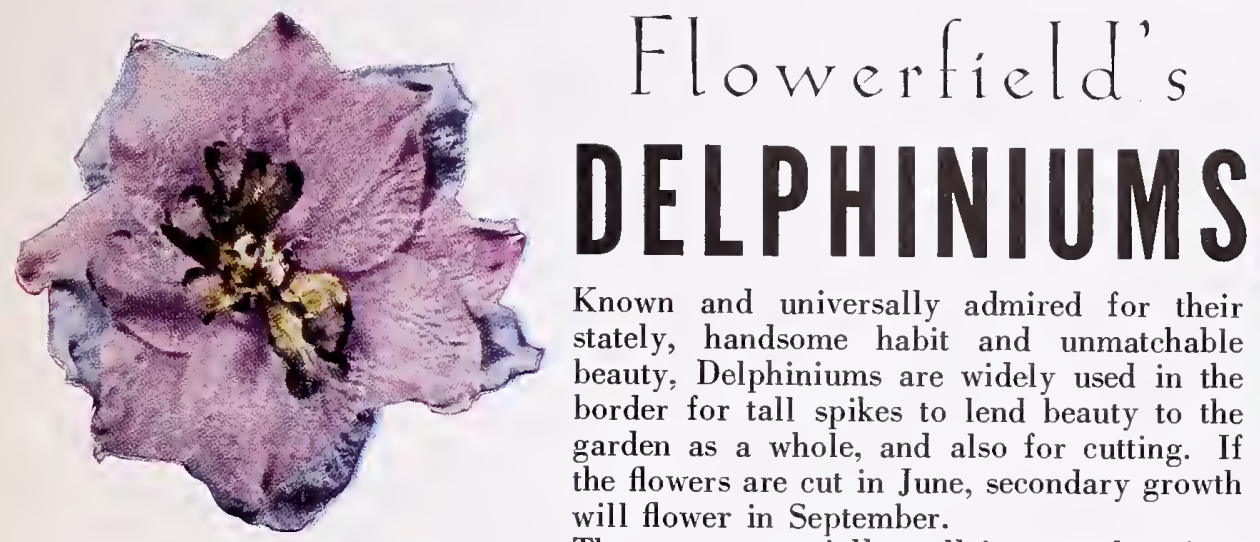

Known and universally admired for their stately, handsome habit and unmatchable beauty, Delphiniums are widely used in the border for tall spikes to lend beauty to the garden as a whole, and also for cutting. If the flowers are cut in June, secondary growth will flower in September.

They grow especially well in coastal regions where cool summers prevail. Plant in rich soil provided with a generous quantity of manure. Full sunlight is essential.

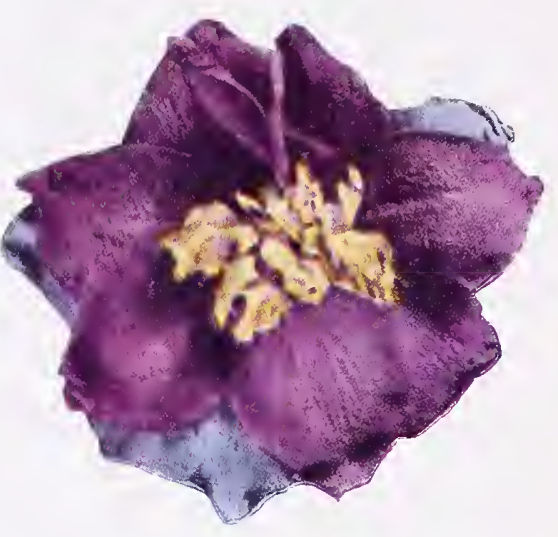

\section{PACIFIC COAST HYBRIDS}

In size of flower, range of color, formation of blooms, and cut flower value, these are the finest strain of Delphiniums in existence. Individual florets measure 2 inches or more across, with practically all of them fully double and finely formed. A variety of "bees", some pure white, others in dark tones, add to their undoubted appeal. Colors vary from pale self-blues through light tones, two-tones, pink shades, lavenders, to really deep blue.

\section{Field Graven Plants}

Blue and Light Blue Tones Violet and Dark Blue Tones White

All Colors and Tones Mixed
Each $75 \mathrm{c}$, Doz. $\$ 7.50$

Each 75c, Doz. $\$ 7.50$

Each 75c, Doz. $\$ 7.50$

Three $\$ 2.00$, Doz. $\$ 6.50$

\section{Named Warieties= Field Plants}

Black Knight Deep violet, black "bees"

Blue Jary Dark blue, dark "bees"

Galahad White Series Pure white, white "bees"

Guinevere Series Light lavender-pink, light blue "bees"

King Arthur Deep blue and blue-violet, white "bees"

Summer Skies Series Azure-blue, with white centers

ROUND TABLE SERIES Mixture of the above 6 varieties
Three $\$ 1.50$, Doz. $\$ 5.00$

Three $\$ 1.50$, Doz. $\$ 5.00$

Three $\$ 1.50$, Doz. $\$ 5.00$

Three $\$ 1.50$. Doz. $\$ 5.00$

Three $\$ 1.50$, Doz. $\$ 5.00$

Three $\$ 1.50$, Doz. $\$ 5.00$

Doz. $\$ 4.50$

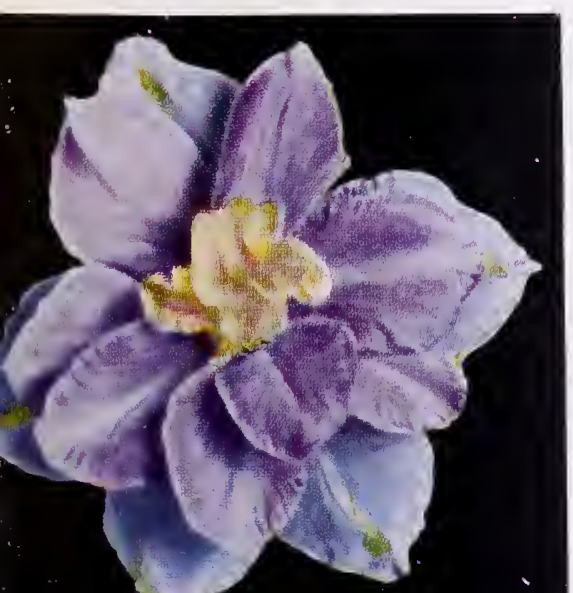

Belladonna, Cliveden Beauty Easily grown in almost any situation, succeeding in warm parts of the country where hybrids "peter" out, Belladonna grows about 3 feet tall, in one pure tone of clear light blue. Invaluable for cutting.

Three \$1.35, Doz. $\$ 4.50$

Bellamosa. Identical in habit and size to Belladonna, but of a rich dark blue.

Three $\$ 1.25$, Doz. $\$ 4.00$

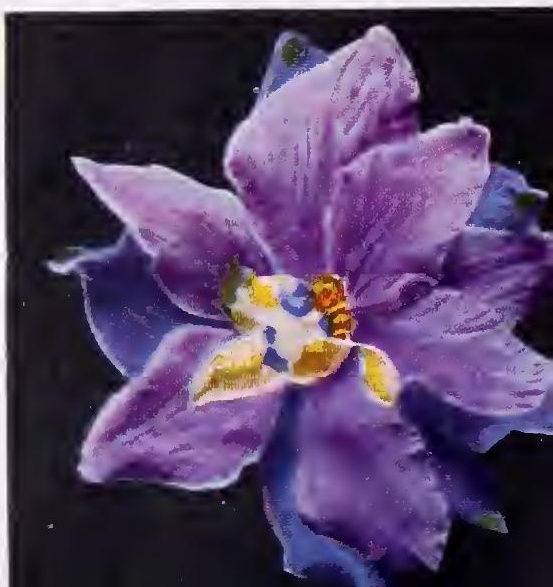


Reine Helene One of the most artistically formed of tbe Iris. Large, ruffled flowers freely produced on tall, stately stems. In the sun Reine Helene is a soft reddisb purple, indoors it seems a lovely violet shade.

65c Each, Doz. $\$ 6.50$

COLLECTION
FOUR OUtSTANDING VARIETIES
Bokhara
Jeanette Parry
4 Pa Favorite
4 Plants 1 of Each $\$ 2.25$
12 Plants 3 of Each $\$ 6.25$
Separately Labeled

A

FLOWERFIELD

SPECIALTY

SINCE

1895

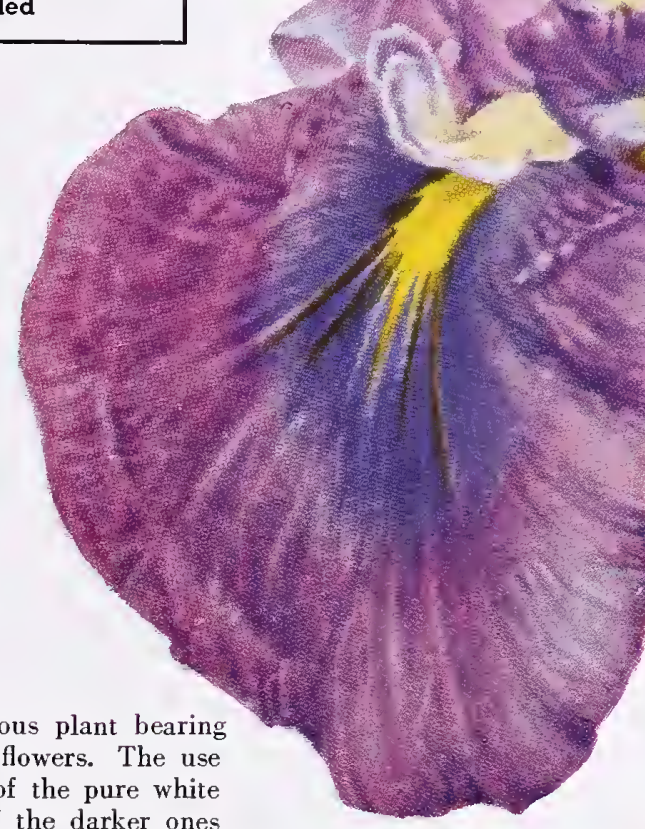

Gold Bound A fine floriferous plant bearing large, double, pure white flowers. The use of Gold Bound, or otbers of the pure white Iris is necessary to set off the darker ones properly. 50c Eacb, Doz. $\$ 5.00$ Jeanette Parry Very large, single petals of light blue are softly veined in deep purple. A single Iris of fine stature and excellent habit.

$50 \mathrm{c}$ Each, Doz. $\$ 5.00$

Koki-No-Iro A large double flower of dark blueviolet with hardly any perceptible veining. Purple and gold in color, it is one of the best known and most dependable of the older varieties of Iris; being known also by the names Pyramid and Midnight. It is extremely lavish with its bloom, and even small plants yield many flowers.

50c Each, Doz. $\$ 5.00$

La Favorite An exceptional double flower. The delicate blue-white color of the falls is faintly laced with fine purple veins, creating an effect of pure white at a distance.

50c Each, Doz. $\$ 5.00$

Light-in-the-Opal One of the most outstanding of all Irises. A gorgeous orchid-pink whose double flowers measure 8 inches or more across. Ruffled at the edges, the throat is circled by a delicate blue halo giving to the entire effect an indescribable beauty. A Flowerfield origination and a masterpiece of which we are justly proud.

$\$ 1.00$ Each, Doz. $\$ 10.00$

Mountain Glacier This large white Iris is tinted with delicate shades of blue, suggesting the beauty of a mountain ice field. Mountain Glacier is a profuse bloomer that combines magnificently with other colors.

75c Each, Doz. $\$ 7.50$

Nishiki-Yama Large vinous mauve double, flushed and veined white. Center of petals banded with mauve. A rare Iris.

75c Each, Doz. $\$ 7.50$

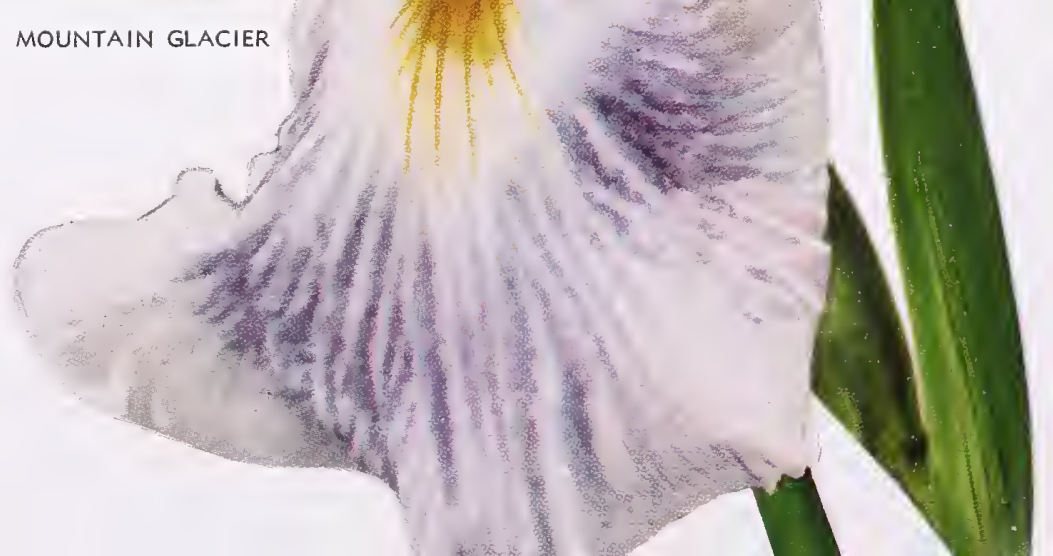




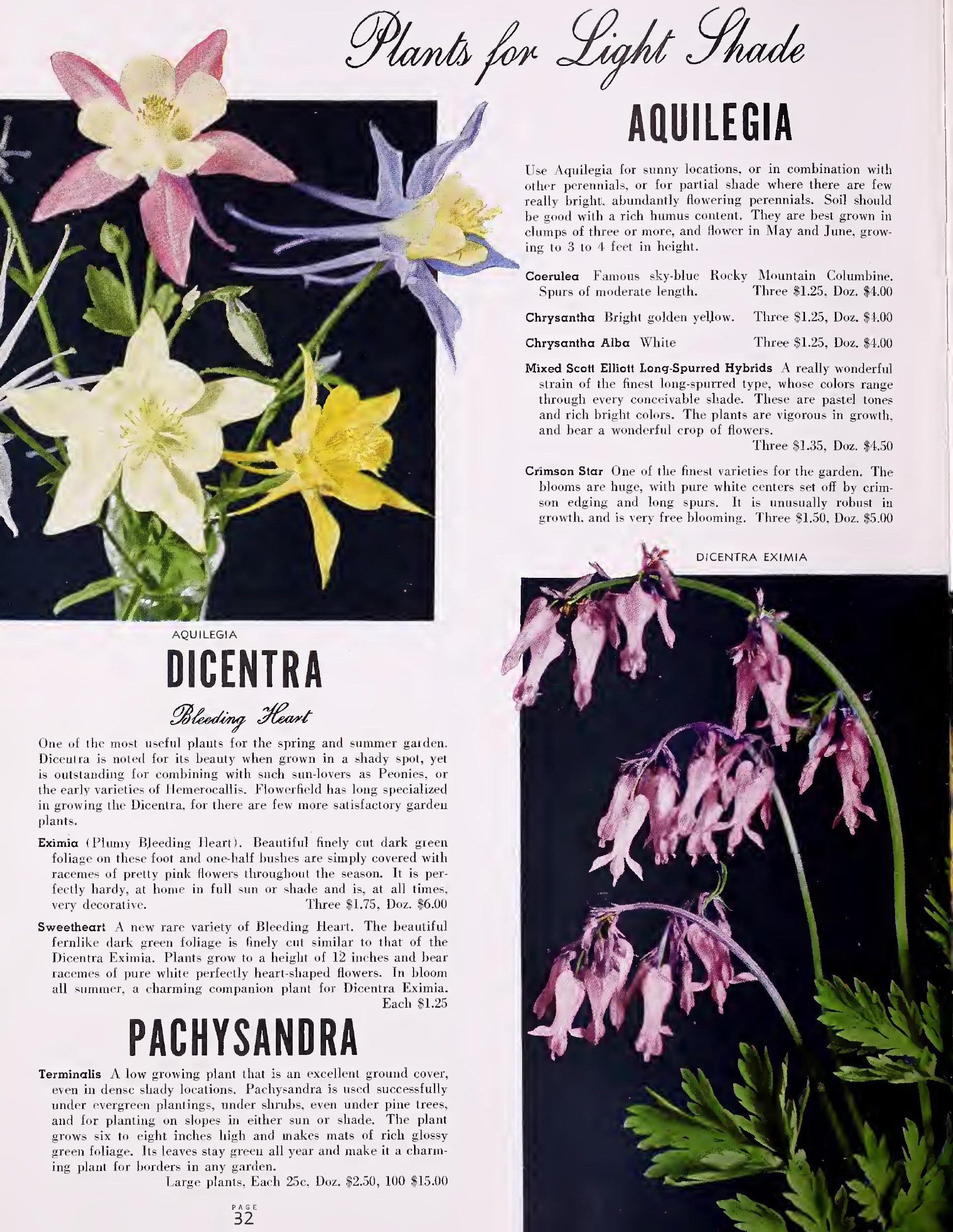




\section{Plants fore \\ Full $\mathscr{S}_{\text {un }}$}

\section{GYPSOPHILA}

\author{
Baby's $\mathscr{B}$ reath
}

Light open sprays of pure white or light pink flowers. An ideal filler for bouquets; it is also cut and dried for use in the winter. The bushiness of the plants makes it useful in garden borders. Prefers full sunlight and a light well-drained soil. Plants should be placed 2 feet apart.

Bristol Fairy A favorite of the home gardener and the florist because of its pure white, fully double flowers. It branches easily and blooms from July throughout the summer. Each 50c, Doz. $\$ 5.00$

Pacifica This variety grows as vigorously as Bristol Fairy but bears flowers of delicate pink. It lends a delightful pastel shade for bouquet use.

Each 50c, Doz. $\$ 5.00$

\section{LIATRIS}

Pycnostachya The purple Kansas Gayfeather or Blazing Star with long Delphinium-like spikes 4 to 5 feet high. Covered with starlike flowers clustered tightly along the strong spikes. When cut for arrangements, it is lovely either by itself or used with stunning effect in combination with Gladiolus. Blooms in August.

Each $50 \mathrm{c}, \$ 2.75$ for $6, \$ 5.00$ per Doz.

\section{GAILLARDIA}

Gay and bright, in bloom from June to November, the Gaillardias will provide an endless source of cut flowers throughout the summer and fall. They will withstand droughts, flowering through the driest of seasons.

Improved Hybrids Bright yellow, pale copper and deep red tones in these mixed hybrids.

Three $\$ 1.35$, Doz. $\$ 4.50$
GAILLARDIA AND GYPSOPHILA PACIFICA

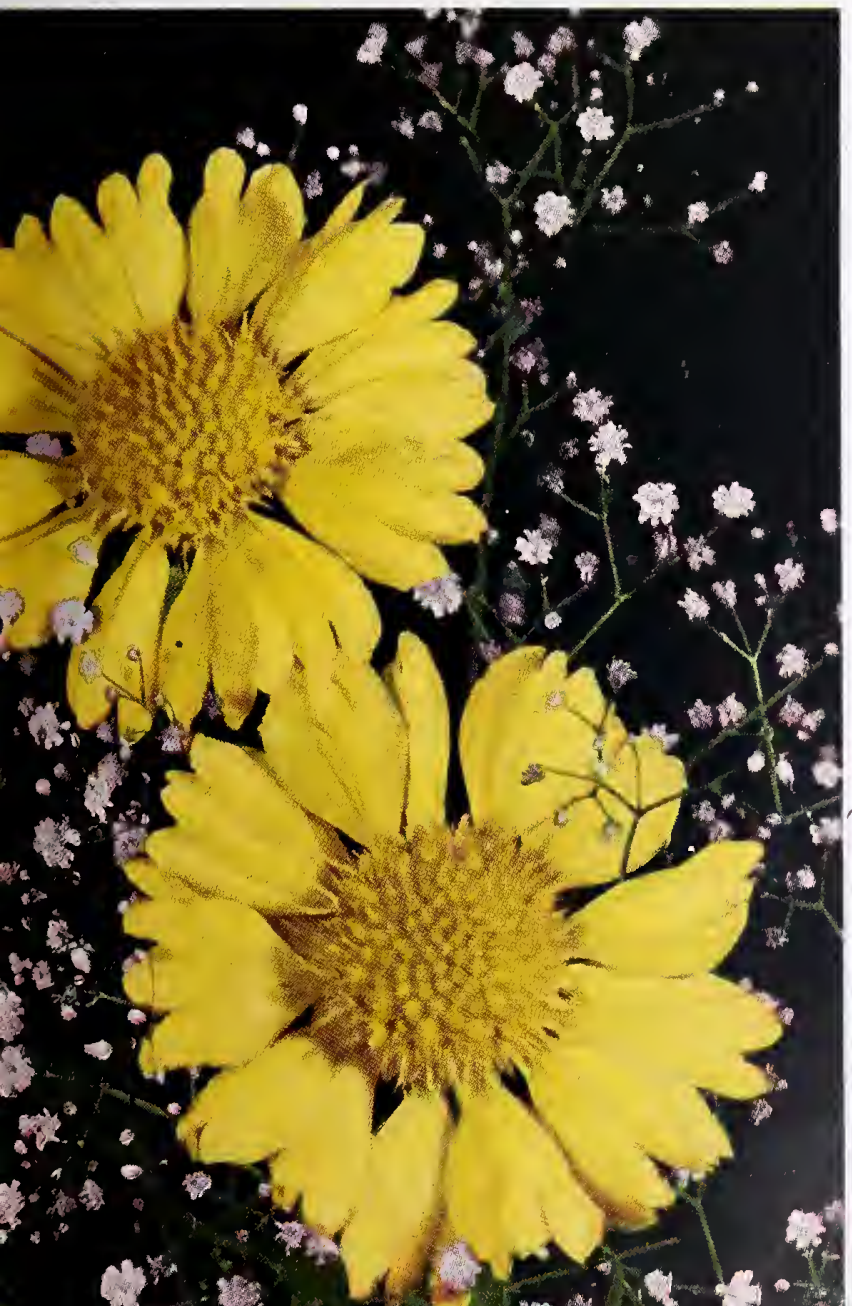

\section{COLLECTION}

3 Gaillardias

3 Gypsophila

All 6 Plants for $\$ 2.25$
HOLLYHOCK, CHAMOIS

\section{DOUBLE HOLLYHOCKS}

Double Hollyhocks are one of the best background plants for your hardy border, in a corner, against a wall, or merely as a mass of color that towers above all the other garden subjects. These unusually lovely blooms are spaced along the full height of their 6-foot flower stalk, and have many beautifully fringed flowers in new and fine shades not previously available in the old-fashioned single Hollyhock.

Chamois

Three $\$ 1.50$, Doz. $\$ 5.00$

Scarlet

Three $\$ 1.50$, Doz. $\$ 5.00$

Newport Pink

Three $\$ 1.50$, Doz. $\$ 5.00$

Mixed Colors

Three $\$ 1.35$, Doz. $\$ 4.50$ 


\section{A CALENDAR OF BLOOM}

A full season of bloom can be enjoyed by your own choice of the varieties listed below:

May: Orange King, Gold Dust.

June, July: Ophir, Thunbergi, The Gem, J. R. Mann.

July: Olif, Patricia.

July, August: Hyperion, Kwanso Flore-Plcno.

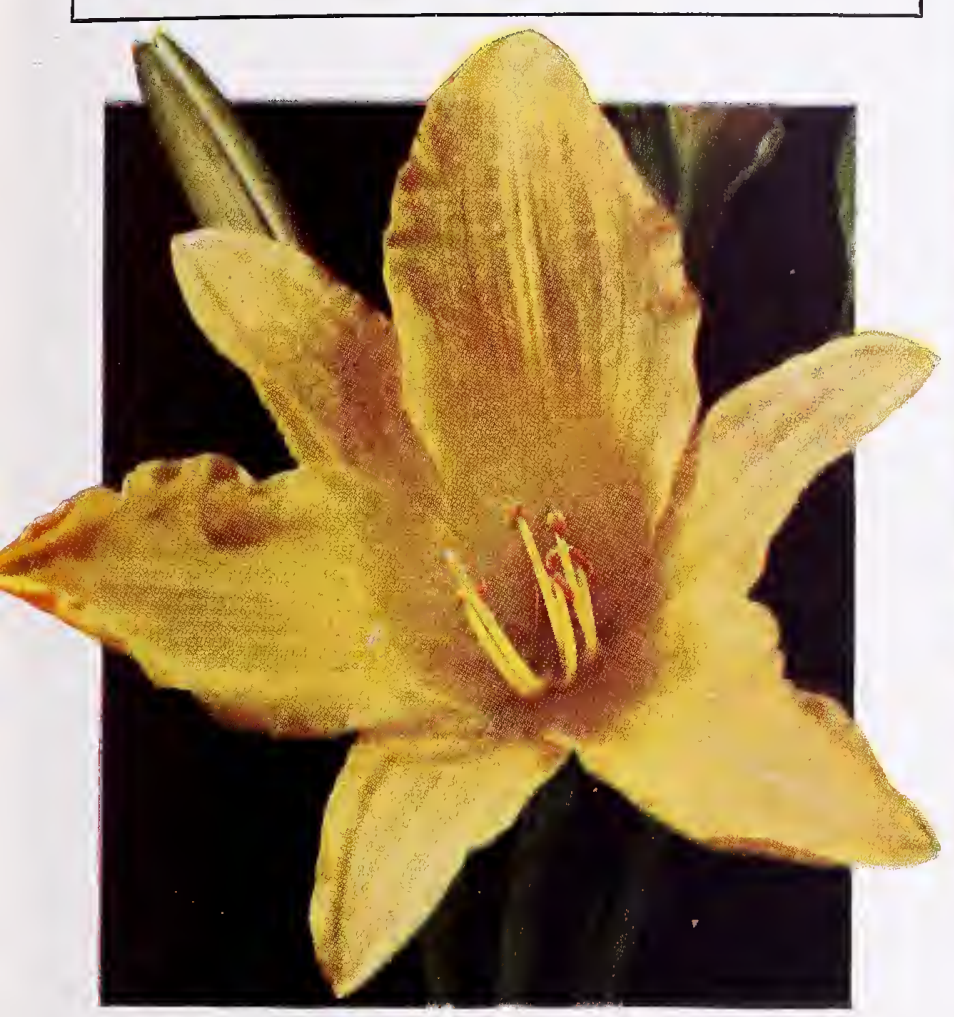

Ophir Large clusters of golden yellow trumpet-shaped flowers, 25 or more to a stem. Flowers have a golden yellow throat flushed with colorful yellow veins in the center of the petals. Blooms in June. Height 36 inches. Illustrated.

Each $75 c$, Doz. $\$ 7.50$

\section{FUNKIA}

\section{The Plantain Lihy}

Coerulea Used in shaded locations and for edging. Tall spikes of blue trumpet-like flowers, 2 feet high, in July and August. All Funkias like rich soil, but grow well anywhere.

Three $\$ 1.25$, Doz. $\$ 4.00$

Coerulea Variegata A beautiful edging plant admired for its colorful foliage as much as for its fine Lily-like blue flowers. The leaves are pure white, heavily marked with bright green.

Three $\$ 1.25$, Doz. $\$ 4.00$

Subcordata Grandiflora Alba In August and September this has tall, Lily-like stems with pure white trumpet flowers 4 inches or more in length. A fine addition to the garden. Excellent for use in shading roots of Lily bulbs.

Three $\$ 2.00$, Doz. $\$ 6.50$

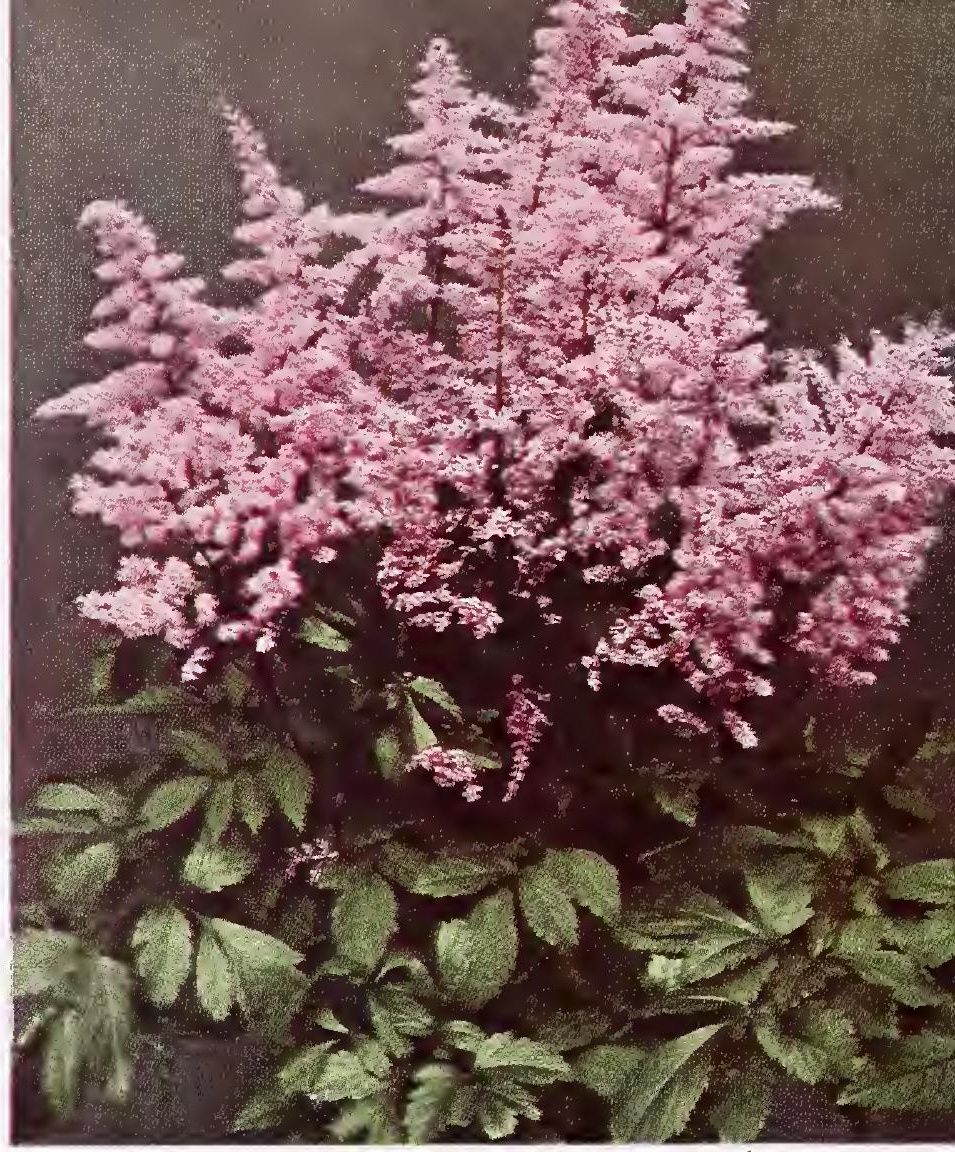

ASTILBE, PEACH BLOSSOM

\section{ASTILBE

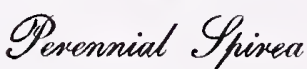

The Astilbe are sturdy, 2- to 3 -foot plants with finely cut attractive foliage that remains attractive throughout the summer. Above this foliage bloom great sprays of very delicate lacy flowers. Astilbe are excellent for shade; however, they may be used in full sun if they have an abundance of water at all times. Because of this the Astilbe are most useful in the damp spots in the garden where most other flowers will not grow. Soil should be deep and rich with plenty of leaf mold and manure. Flowerfield's Astilbe are one of the hardiest of plants, standing the most severe winters.

Deutschland The finest pure white variety, free flowering and of strong growth. An ideal white plant for your evening garden.

Three $\$ 1.50$, Doz. $\$ 5.00$

Fanal This brilliant new Spirea combines all the fine attributes of its sister varieties with a new color in Spireas-deep magentared. It is so brilliant that it commands attention from any angle. Astilbe Fanal is one of the best new plants.

Each $\$ 1.00$, Doz. $\$ 10.00$

Peach Blossom Great feathery plumes of pale pink flowers. The picture above displays its fine beauty.

Three $\$ 1.50$, Doz. $\$ 5.00$

\section{COLLECTION}

One Each of the Above Astilbes

3 PLANTS $\$ 1.75$ 


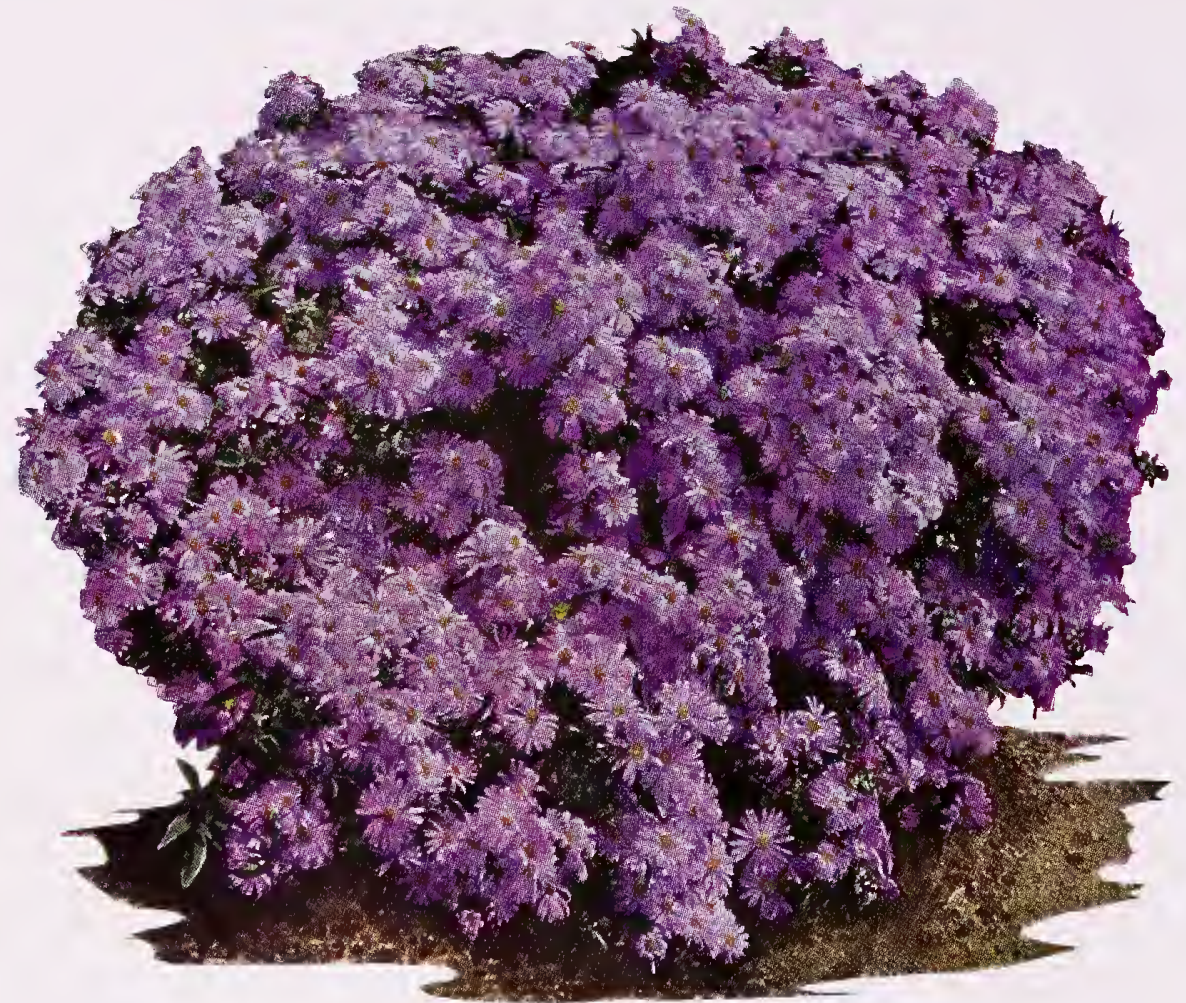

VIOLETTA

The picture describes this lovely Aster. If this is what you want in an Aster, Violetta will supply your needs. The bush pictured is about 2 feet high. It is truly in a class by itself. The blooms are so close together that the foliage is not visible in the mounds of color. Violetta fits into any garden, large or small.

Three $\$ 1.75$, Doz. $\$ 6.00$
Flawexfield's

HARDY

FLOWERFIELD Hardy Asters are invaluable for that late between seasons lull in the garden. Blooming between the last of the summer perennials and the late fall Chrysanthemums, these colorful Daisy-like flow-

Beechwood Challenger Free flowering, of medium height, and brilliant crimson-red color. 3 to 4 feet. Undoubtedly today's finest red Aster. One of the most brilliant colors of the hardy Asters.

Three $\$ 1.50$, Doz. $\$ 5.00$

Climax One of the best and showiest, with large spikes of light lavender-blue flowers. This tall variety blooms very freely and by its height is a highlight of the garden. Grows to 5 feet.

Three $\$ 1.50$, Doz. $\$ 5.00$

Harrington's Pink One of the finest of the fall Asters, and the only one that is really a pure pink in color. The plants are shapely in habit, growing about $31 / 2$ feet tall. Great sprays of blooms are carried, with individual florets of large size, suitable for cutting. Three $\$ 1.50$, Doz. $\$ 5.00$

\section{ASTER COLLECTION}

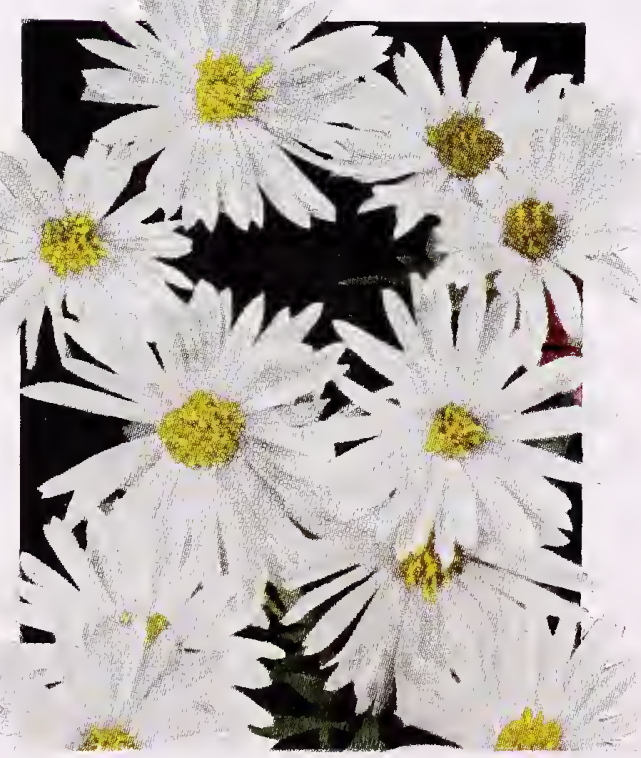

MOUNT EVEREST

By far the finest and best white. Flowers are large, pure white, with a very small eye. In growth the plants are shapely, with the flowers carried right down to the ground. $3 \frac{1 / 2}{2}$ feet high.

Three $\$ 1.35$, Doz. $\$ 4.50$
Mt. Everest

Red Rover

Violetta

Harrington's Pink

All Four

ONE OF EACH

$\$ 1.75$

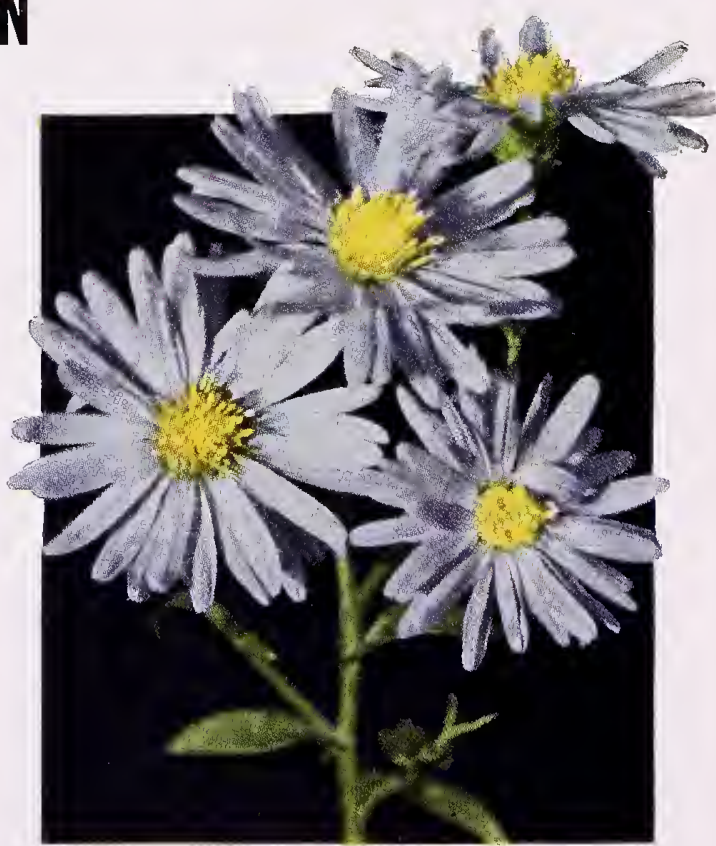

AMETHYST

A beautiful shade of purple-blue with almost double petals. It is free-flowering and is the finest in its color range.

Three $\$ 1.50$, Doz. $\$ 5.00$ 


\section{SELECTED HARDY CHRYSANTHEMUMS}

\section{TALL GROWING HARDY MUMS}

These large-flowered Hardy "Mums" have been selected from the very best new hybrids. and the most rugged of the old favorites. Their color range is comprehensive, containing bright, warm colors that add glow to the autumn garden, light pastels for cutting, and russet and bronze tones without which fall is not complete.

Chrysanthemums are of easy culture, and if planted this spring, will give huge clumps of blooms beginning in September and continuing until hard frost. For best results, "Mums" should be planted in a slightly elevated well-drained location. We ship only the finest heavy-rooted pot plants. (These prices include shipping charges.)

Agnes Selkirk Clark Shown in picture at right, this is a fine autumn shade reminding one of Halloween, Thanksgiving and all the good things of the fall.

Each $40 \mathrm{c}$, Doz. $\$ 4.00$

Avalanche Possibly the finest white Chrysanthemum for the garden. Very large, double, pure white hlossoms are carried on well-branched sprays. It flowers in late September, so is valuable where frosts are early.

Each 50c, Doz. $\$ 5.00$

Caliph A fine velvety dark red that is outstanding in its color group. (Pictured.)

Each $45 \mathrm{c}$, Doz. $\$ 4.50$

Daphne A fine Daphne-pink. Blooms very profusely and is the soft pink that suits any garden. (Pictured.)

Each $40 \mathrm{c}$, Doz. $\$ 4.00$

Ember The color of Ember is copper-bronze, as shown in the picture at right. The plants are well covered with these glowing blooms.

Each 45 c, Doz. $\$ 4.50$

Eugene Wander A fine big yellow that in many ways is the equal of King Midas, but a deeper yellow. The flowers are finely formed, but very large, sometimes quite weighing down the stalks. Its earlier blooming period makes this a very important variety in the garden. Each 55c, Doz. $\$ 5.50$

Indian Summer A fine tawny orange illustrated at lower left of picture. A tall variety, may be used to advantage back of the lower growing Cushion Mums.

Each $40 \mathrm{c}$, Doz. $\$ 4.00$

Jean Cumming Without question, the standard white variety. Pure white, just a touch of cream in the center, to light the fully double petals. Illustrated in center of picture.

Each 60c. Doz. $\$ 6.00$

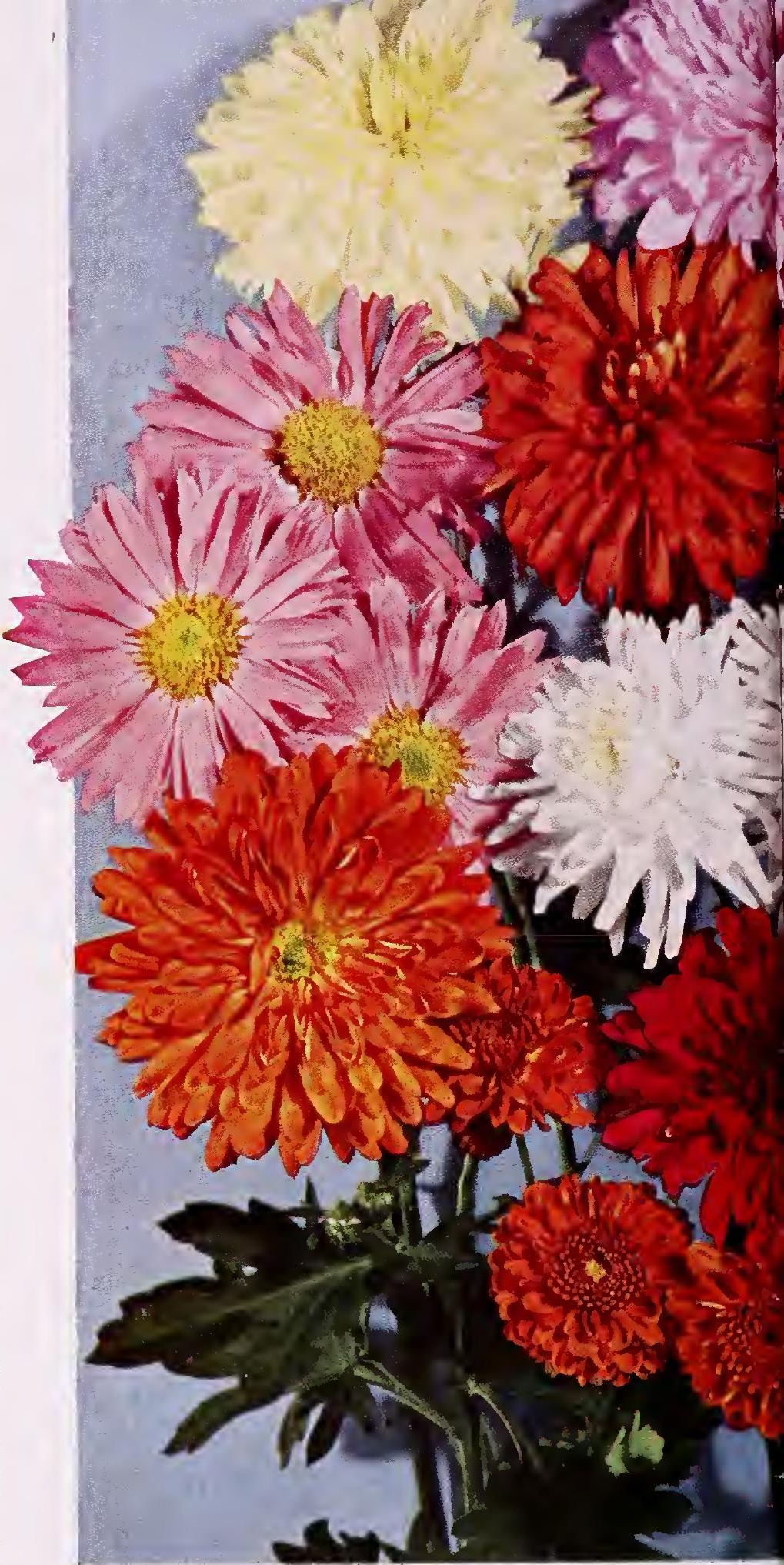

\section{Chrysanthemum} Collection

Varieties in the Group Picture

Separately Packed and Labeled

\section{PLANTS $\$ 4.75$}




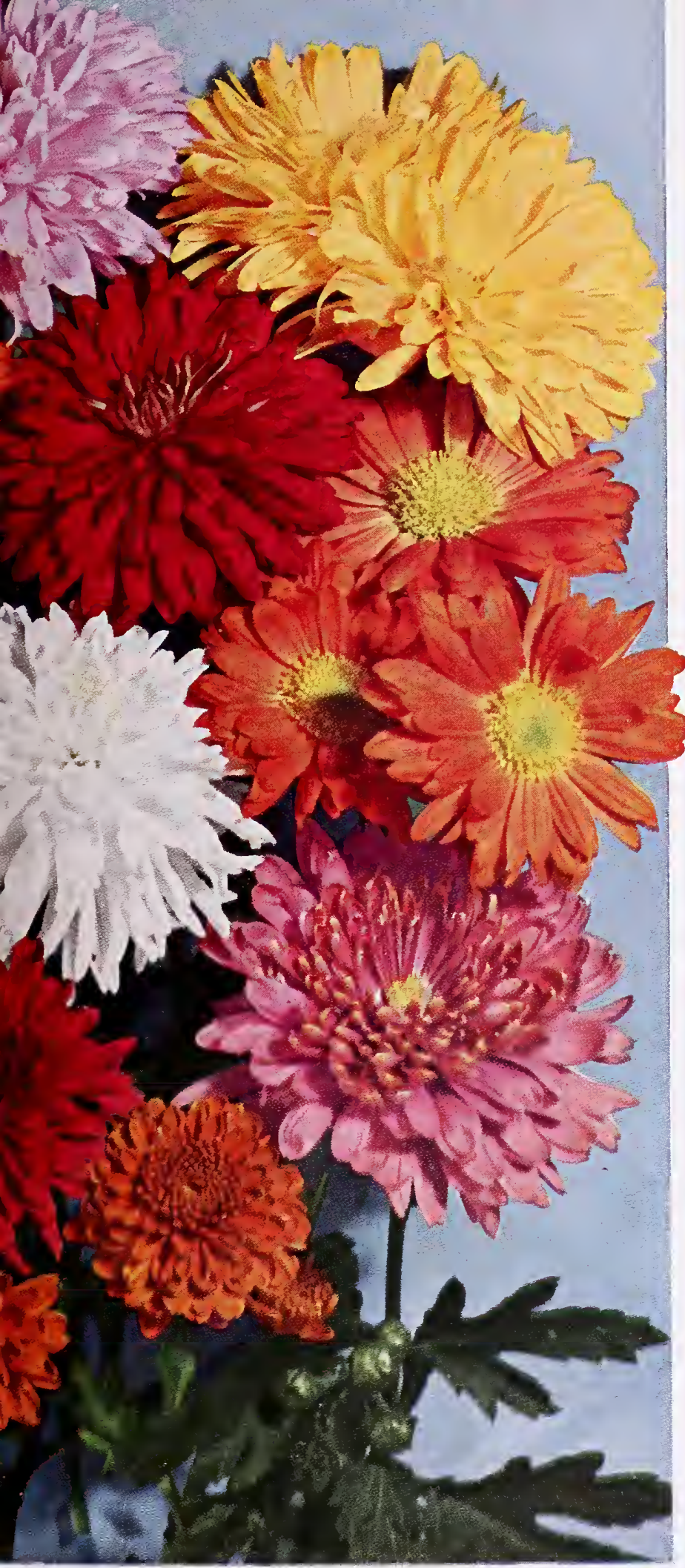

King Midas There are very few Chrysanthemums that can compare with King Midas. The illustration in the upper right does not do this particular flower full justice, for it is one of the largest and brightest of the yellows. It lasts longer than almost any other Mum we know, and it is ideal for cutting, being tall and well-branched, and quite covered with bloom. Finally, it is of the desirable hardy Korean type.

Each 50c. Doz. $\$ 5.00$

Lavender Lady The best known of the new Chrysanthemums, Lavender Lady is particularly prized for use in arrangements where the soft lavender tone combines beautifully with almost any other garden subject. Lavender Lady has the advantage of an extremely long flowering season. Illustrated.

Each $50 \mathrm{c}$, Doz. $\$ 5.00$

Mrs. Pierre S. Dupont III A soft, delicate peach. This fine new Mum has a luminous sheen io its flower that quite sets it apart from others. The large, full, perfectly formed flowers are carried on tall branching stems, making a stunning $2 \frac{1}{2}$-foot plant.

Each $50 \mathrm{c}$, Doz. $\$ 5.00$

Pale Moon Illustrated in the upper left of the picture, Pale Moon is one of the finest and brightest very light cream-colored Mums. Excellent for arrangements or the garden.

Each 50c, Doz. $\$ 5.00$

September Dawn A clear rose-pink, flowering early. Grows about 21/2 feet. Very double and a delightful shade for indoor decoration.

Each 60c. Doz. $\$ 6.00$

Symphony An unusual deep rose shown in the lower right of the picture. A well-liked variety.

Each $50 \mathrm{c}$, Doz. $\$ 5.00$

The Moor Probably the best red Chrysanthemum we have. The Moor, an even more brilliant red than shown in the picture at the left, is one of the very best of the dark colored Korean Chrysanthemums.

Each 50c, Doz. $\$ 5.00$

\section{BUTTON CHRYSANTHEMUMS}

These little fellows with their definite, pure colors, provide just the right piquant note for contrast with the larger varieties. Good for cutting and "made to order" for boutonnieres.

Elfin Shown in the lower center part of the picture, Elfin is one of the best of the "buttons." Being extremely floriferous, the well. branched plant is simply covered with these fine bronze-colored miniature flowers.

Each 50c, Doz. $\$ 5.00$

Nuggets Tight golden flowers that cover the plant. The brightness of this yellow stands out beautifully in the fall garden.

Each 50c, Doz. $\$ 5.00$

Ruby Pompon The best red Chrysanthemum in any class, big or little. Ruby Pompon is the brilliant color its name implies, and has by far the most flowers of the red Mums. Grows only to medium height ( 2 to 3 feet).

Each 50c, Doz. $\$ 5.00$

\section{COMPACT MUMS FOR EDGING}

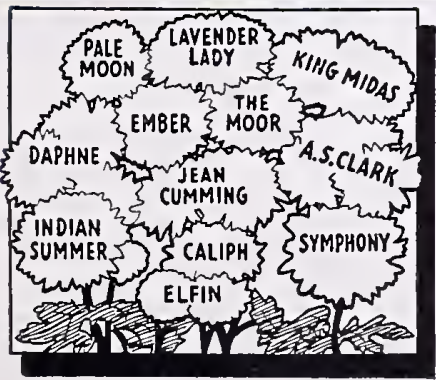

September Cloud Deep drifts of beautifully rounded blossoms, pures white shading to faint primrose in the center, contrast beautifully with the dark green foliage. The plants are nicely rounded, compact and completely covered with flowers from mid-September until frost. Three $\$ 1.50$, Doz. $\$ 5.00$

September Gold Brilliant golden yellow blossoms, trim and neat, twenty-five or more to a spray, completely cover the shapely, wellrounded plants by mid-September and go on until the season's end. Colorful mounds, 18 inches in height.

Three $\$ 1.50$, Doz. $\$ 5.00$ 


\section{Flowerfield's SHASTA DAISIES}

Shasta Daisies are extremely popular, and are very widely grown for their abundance of pure white Daisy-like flowers during the summer months. Shasta Daisies require a deep rich soil in a sunny location. They can remain in one spot indefinitely without attention.

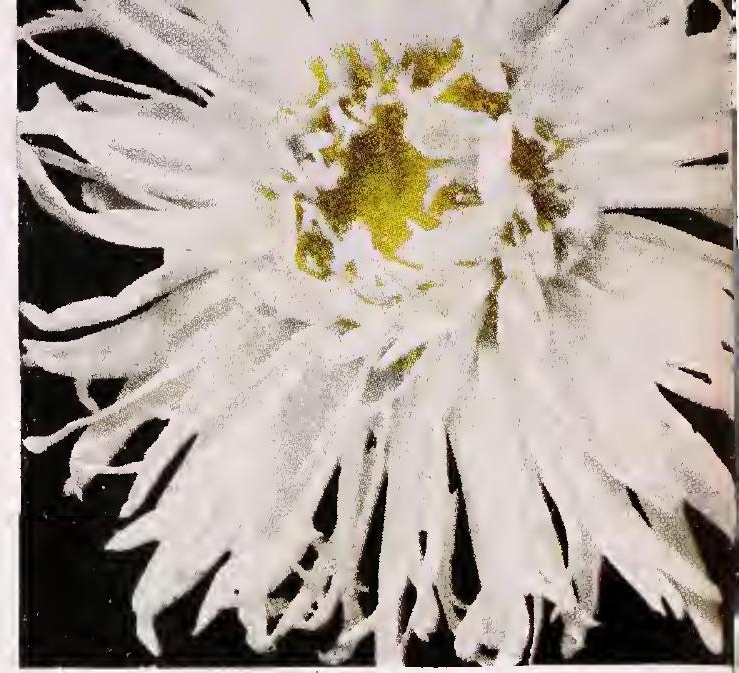

MARCONI
Alaska Alaska is a very large flowering single, that is very similar in appearance to the white Daisy, however, much larger in size. It is one of the best of the single-flowered types of Chrysanthemum Maximum.

Three $\$ 1.35 ;$ Doz. $\$ 4.50$

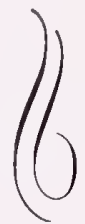

Chrysanthemum Leucanthemum, White Swan. A somewhat smaller-flowered form of the popular Shasta Daisy. White Swan blooms in May and has earned the name of Memorial Day Double Daisy. Lovely, double white flowers in great profusion with as many as twenty to thirty flow. ers on a plant. Height $21 / 2$ feet. Three $\$ 1.50$, Doz. $\$ 5.00$

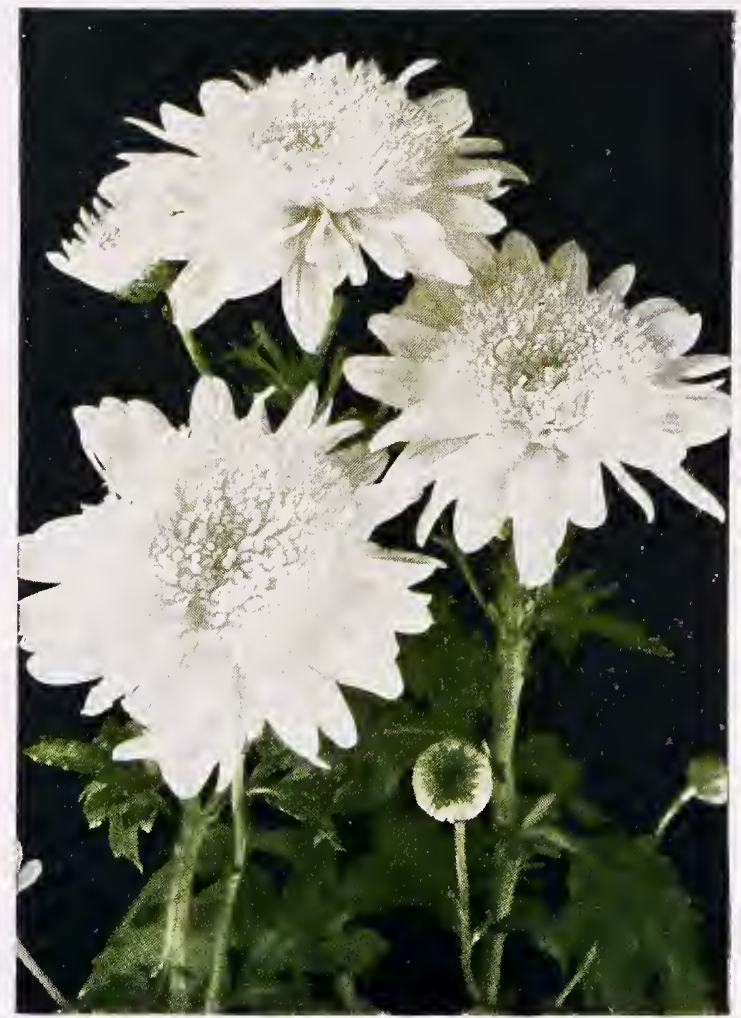

ESTHER REED
Marconi New form of the Shasta Daisy. Golden centers, surrounded by raylike, tubular petals, giving the entire flower a graceful, frilled effect. Flowers measure 31/2 inches across, with stems 2 feet tall.

Three $\$ 2.00$, Doz. $\$ 6.50$

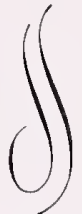

Esther Reed The finest double Shasta Daisy, ideally suited for cut flowers is now widely grown by florists for that purpose. The flowers are pure white, fully double, with a heavy, slightly tufted center, 18 inches high.

Three $\$ 2.00$, Doz. $\$ 6.50$

ALASKA

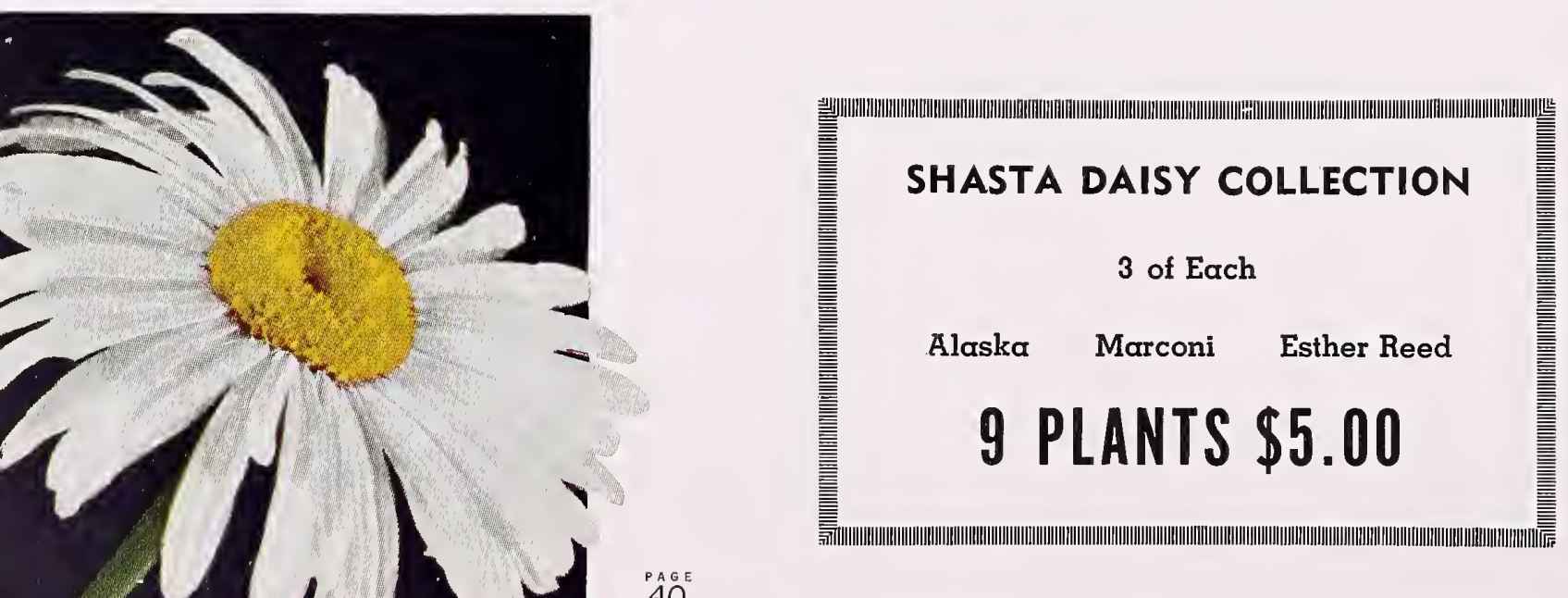




$$
\begin{aligned}
& \text { FlowerFIEL D B B B B B FARM } \\
& \text { Flowerfield, Long Island, N. Y. }
\end{aligned}
$$

Ship to

\section{Freight or Express}

Address if Different

From Post Office

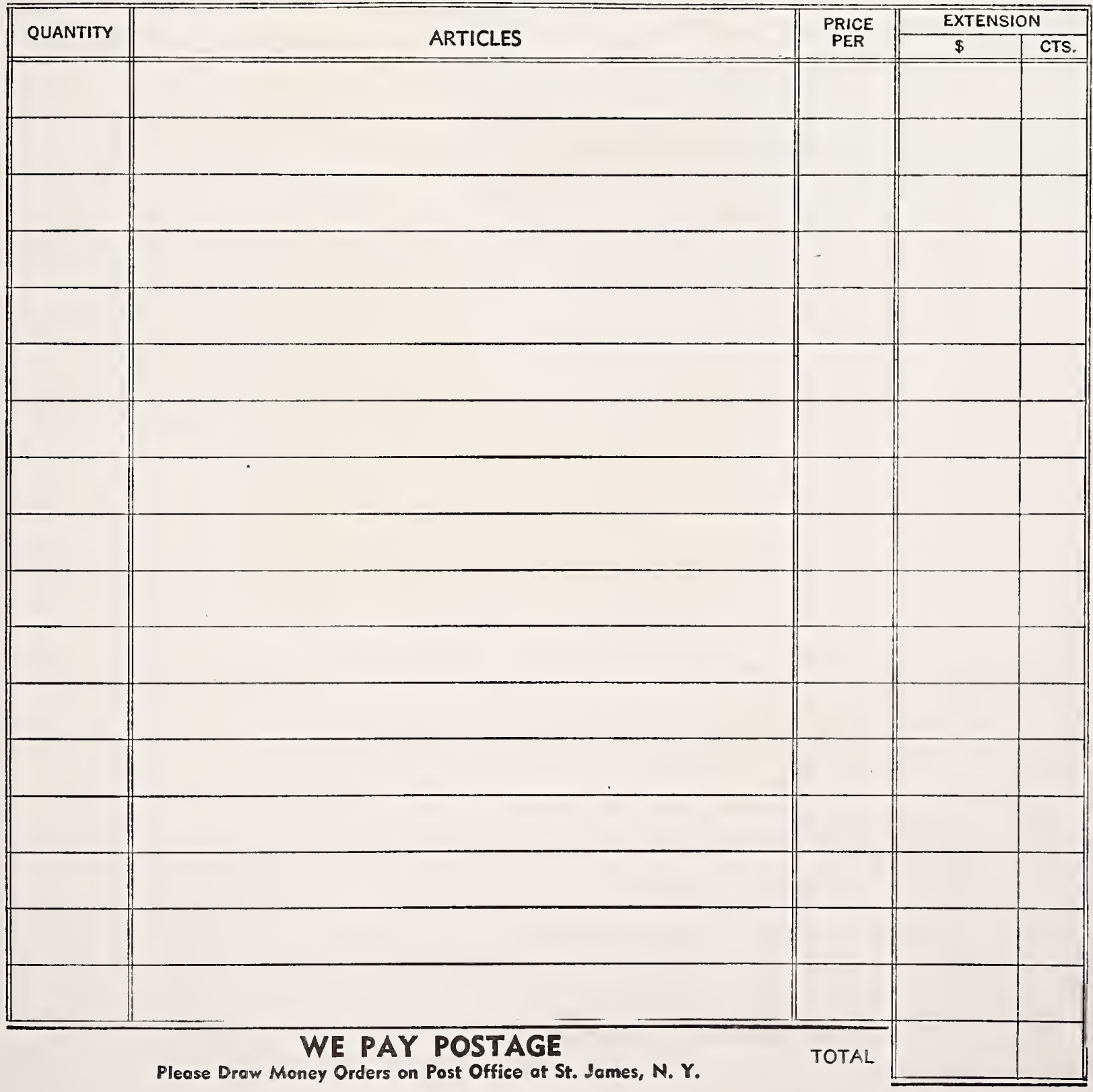


Flowerfield Bulb Farm

Flowerfield, Long Island, N.Y.

\begin{tabular}{|c|c|c|c|c|}
\hline \multirow{2}{*}{ QUANTITY } & \multirow{2}{*}{ ARTICLES } & \multirow{2}{*}{$\begin{array}{l}\text { PRICE } \\
\text { PER }\end{array}$} & \multicolumn{2}{|c|}{ EXTENSION } \\
\hline & & & $\$$ & CTS. \\
\hline & & & & \\
\hline & & & & \\
\hline & & & & \\
\hline & & & & \\
\hline & & & & \\
\hline
\end{tabular}

From

Town

State

Flowerfield Bulb Farm

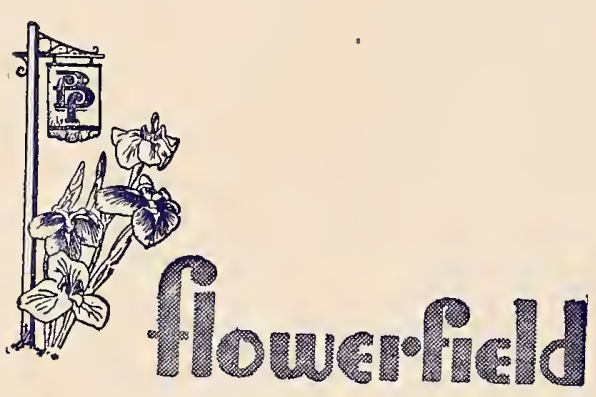

Flowerfield,

Long Island, N. Y. 


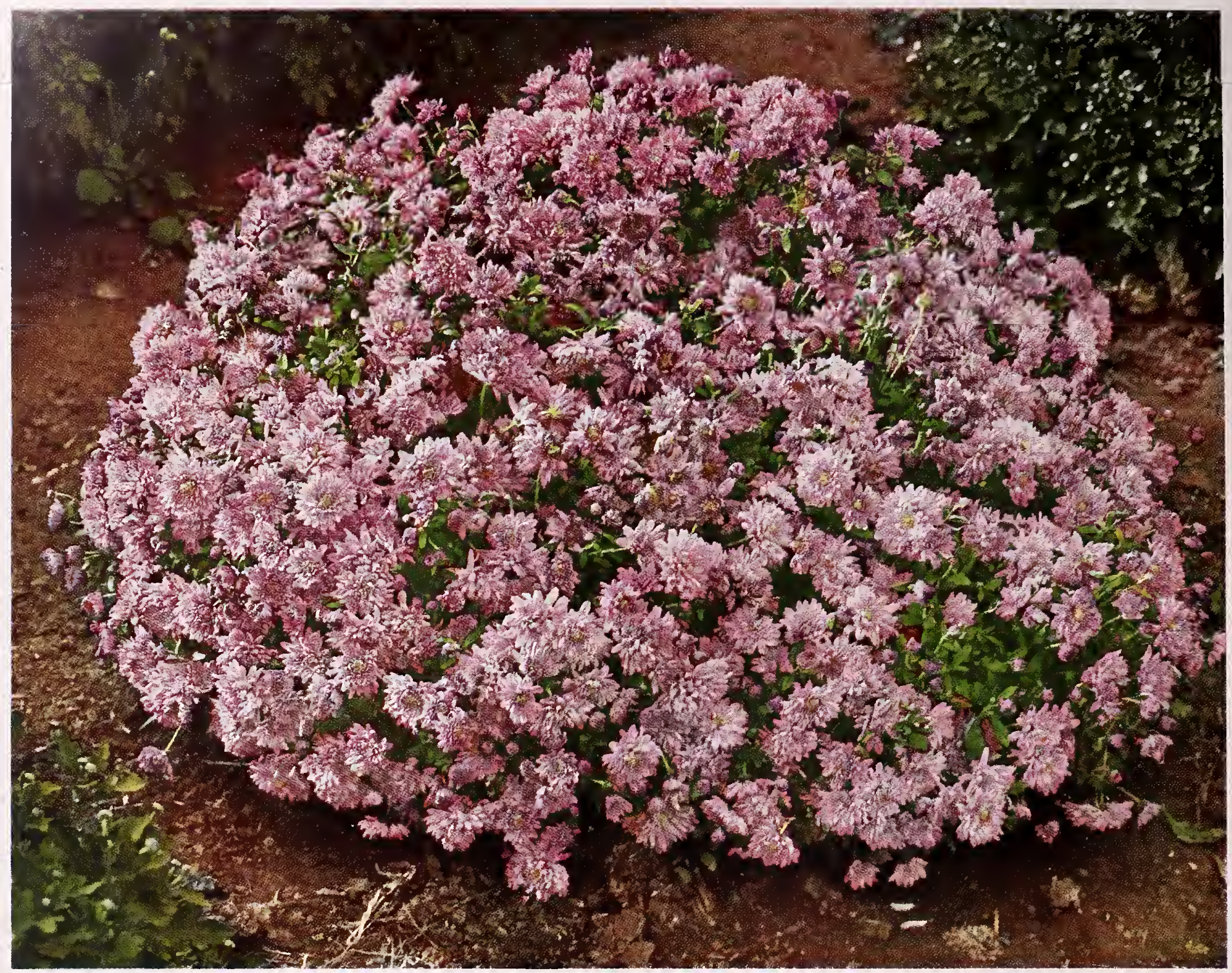

Cushion Chrysanthemum, Major

Each 50c, Doz. $\$ 5.00$

See page 41 for other Cushion Mums and pages 38 and 39 for regular Hardy Mums.

\section{Flowerfield Bulb FArm incorosertio \\ Flowerfield, Long Island, N.Y.}

